Article

\title{
Impact of Substitution Pattern and Chain Length on the Thermotropic Properties of Alkoxy-Substituted Triphenyl-Tristriazolotriazines ${ }^{\dagger}$
}

\author{
Thorsten Rieth ${ }^{1}$, Natalie Tober ${ }^{1}$, Daniel Limbach ${ }^{1}$, Tobias Haspel ${ }^{1}$, Marcel Sperner ${ }^{1}$ (D), \\ Niklas Schupp ${ }^{1}$, Philipp Wicker ${ }^{1}$, Stefan Glang ${ }^{1}$, Matthias Lehmann ${ }^{2, *}$ and Heiner Detert ${ }^{1, *}$ \\ 1 Department for Chemistry, Johannes Gutenberg-University, 55099 Mainz, Germany; \\ thorstenrieth@gmx.de (T.R.); ntober@students.uni-mainz.de (N.T.); Limbach@ghc.de (D.L.); \\ t.haspel@gmx.de (T.H.); marcel.sperner@outlook.de (M.S.); nschupp@students.uni-mainz.de (N.S.); \\ pwicker@students.uni-mainz.de (P.W.); stglang@gmx.de (S.G.) \\ 2 Institute for Organic Chemistry, Julius-Maximilians-University, 97074 Würzburg, Germany \\ * Correspondence: matthias.lehmann@uni-wuerzburg.de (M.L.); detert@uni-mainz.de (H.D.); \\ Tel.: +49-931-318-3708 (M.L.); +49-6131-3924-189 (H.D.) \\ + Dedicated to Horst Kunz, Mainz, on the occasion of his 80th birthday. \\ Academic Editors: Viorel Circu, Doina Manaila-Maximean and Valery A. Loiko

Received: 28 October 2020; Accepted: 2 December 2020; Published: 7 December 2020

\begin{abstract}
Tristriazolotriazines (TTTs) with a threefold alkoxyphenyl substitution were prepared and studied by DSC, polarized optical microscopy (POM) and X-ray scattering. Six pentyloxy chains are sufficient to induce liquid-crystalline behavior in these star-shaped compounds. Thermotropic properties of TTTs with varying substitution patterns and a periphery of linear chains of different lengths, branching in the chain and swallow-tails, are compared. Generally, these disks display broad and stable thermotropic mesophases, with the tangential TTT being superior to the radial isomer. The structure-property relationships of the number of alkyl chains, their position, length and structure were studied.
\end{abstract}

Keywords: star-shaped compounds; discotic liquid crystals; X-ray diffraction; differential scanning calorimetry; polarizing optical microscopy; swallow-tail; heterocycles; structure-property relation

\section{Introduction}

Tristriazolotriazines (TTTs), with a threefold alkoxyphenyl substitution [1-4] (Figure 1), not only belong to the youngest classes of discotic liquid crystals (DLCs) [5-16] but also to the small subgroup of DLCs with a heterocyclic [17-26] and electron-deficient core [27-36]. Two $C_{3}$-symmetrical isomeric forms of these star-shaped molecules are known: the paddle-wheel with phenyl substituents in tangential positions ( $t$-TTT) 1 , and, if the aromatic rings are attached to the radial positions, the propeller $(r$-TTT) 2 (Figure 1). This ostensible small change from tangential to radial substitution severely alters the mesomorphic properties. The $t$-TTT is a reliable core for discotic liquid crystals with broad mesophases [1-4,37-40], and phenyl substituents on this isomer are twisted out of the mean plane by $21-80^{\circ}$ [41]. Isomerization to the $r$-TTT provokes a flattening of the aromatic part and facilitates crystallization. Reduced or even complete loss of mesomorphism is the typical consequence for 3,4- and 3,5-dialkoxy derivatives [42]. On the contrary, derivatives with a 3,4,5-trialkoxy periphery have lower melting points and broader phases. Although calamitic LCs have contributed to a broad range of technical innovations, discotic LCs have only found selected applications, such as in optical compensating films or sensors [9]. Understanding the structure and molecular dynamics is not a trivial task. The comprehension of structure-property relationships is the key knowledge to tailor 
mesomorphic, optical and electrical properties for the application of DLCs as anisotropic organic semiconductors in organic field-effect transistors, light-emitting diodes or photovoltaic devices [13]. Columnar phases of DLCs comprise stacks of disk-like molecules arranged on a regular 2D-lattice. Redox potentials and charge carrier mobilities are central properties for electronic applications; the latter is highly dependent on intermolecular order, allowing orbital overlap, e.g., in staggered cofacial conformations [14] or helical arrangements [15]. According to a theoretical study on columnar mesophases of TTTs with an electron-rich periphery, a high number of $\pi$-stacking contacts [16] render an ambipolar charge transport in TTTs on two main charge transport channels. Cyclic voltammetry of alkoxyphenyl TTTs showed only nonreversible oxidation [2], whereas the TTT core was shown to have electron-transporting characteristics [43]. The hole-transporting HOMO orbitals are located in the peripheral region; the LUMO orbitals, located in the central TTT, take the electron transport. From impedance spectroscopy, it is concluded that the conductivity in the columnar phase of dialkoxy-TTTs is mostly ionic (low-frequency regime), probably due to ionic impurities [2].
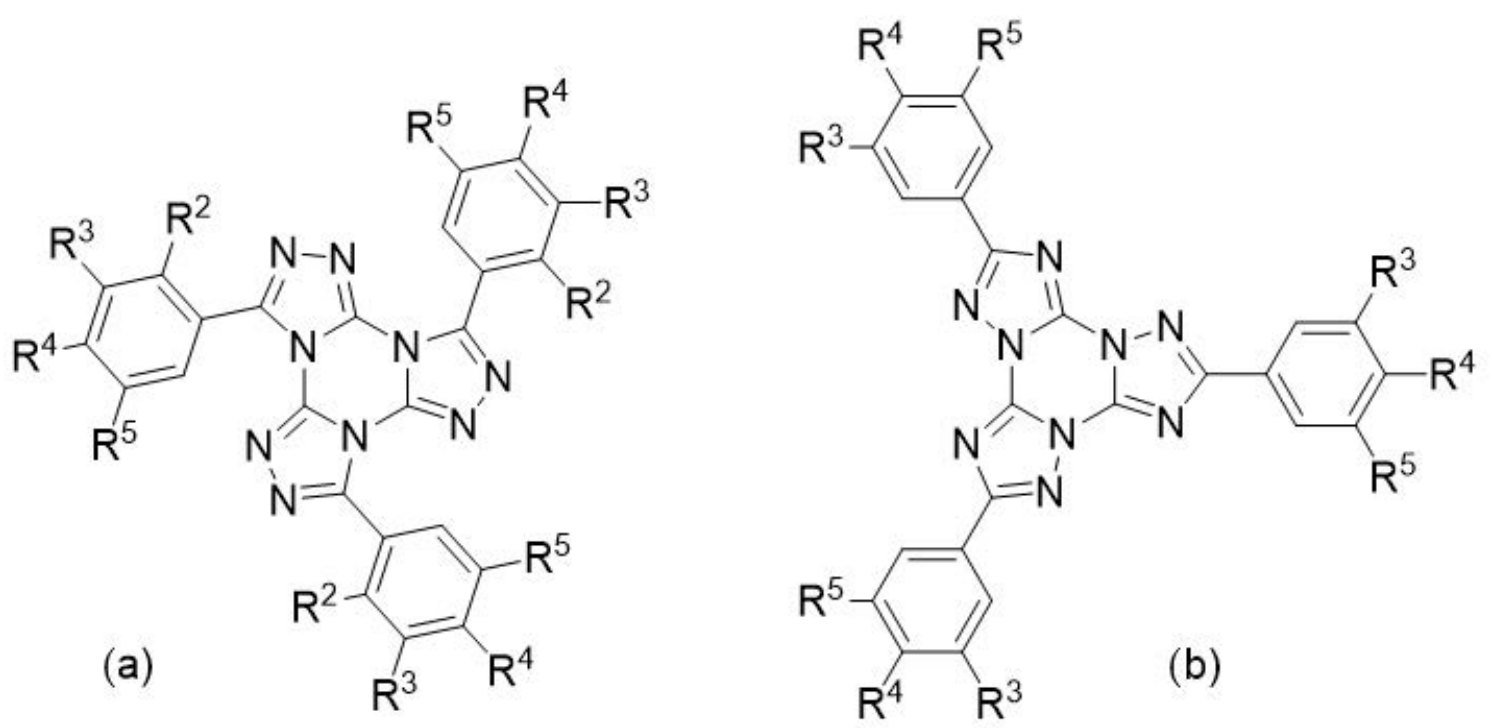

Figure 1. Tangential tristriazolotriazines ( $t$-TTTs) (a) and propeller tristriazolotriazines $(r$-TTTs) (b) and the substitution pattern.

The established option for the mesophase engineering of DLCs is the variation of the periphery. The number, length, position, composition and structure of flexible side chains form a highly advantageous toolbox for custom-made mesomorphism and have been extensively studied, e.g., on triphenylenes [44,45], star systems [46-49] and macrocyclic discs [50-55]. Though some general trends have been found and successfully used for the prediction of liquid crystal (LC) behavior, they are valid only for a certain core [7]. Furthermore, the scientist is often rewarded with nonlinearities and surprising exceptions. The objective of this report is to elucidate the correlation between the mesomorphism of TTTs and the composition of their periphery. This includes the number of side chains, the variation of their position, their length and branching.

\section{Results}

\subsection{Synthesis}

The only effective synthesis of $t$-TTTs is the threefold acylation/ring transformation of tetrazoles with cyanuric chloride (Scheme 1), according to Huisgen [56]. A few compounds require minor modifications, but the main problem is the chromatographic separation of diaryl triazoles $\mathbf{3}$ formed as by-products. Alkoxyaryl-tetrazoles 6 are accessible via the addition of azide to alkoxybenzonitriles 4 or, if the respective hydroxybenzonitrile is not available, via the dehydration/azidination of 
alkoxybenzamides 5 with triazidochlorosilane [57]. Despite earlier accounts [1,2], $t$-TTTs $\mathbf{1}$ are sensitive to high temperatures. A thermal isomerization converts 1 to its isomer $\mathbf{2}$ with different connectivity of the triazole rings, shifting the tangentially oriented aryl rings to radial positions. The cyclocondensation of chlorotriazoles 7 is the direct route to the isomeric $r$-TTTs 2 [58,59]. Besides limited accessibility of the particular chlorotriazole, poor yields in the cyclocondensation step reduce the synthetic value of this method. Therefore, nearly all $r$-TTTs known today were obtained by thermal isomerization of the tangential isomer [42].

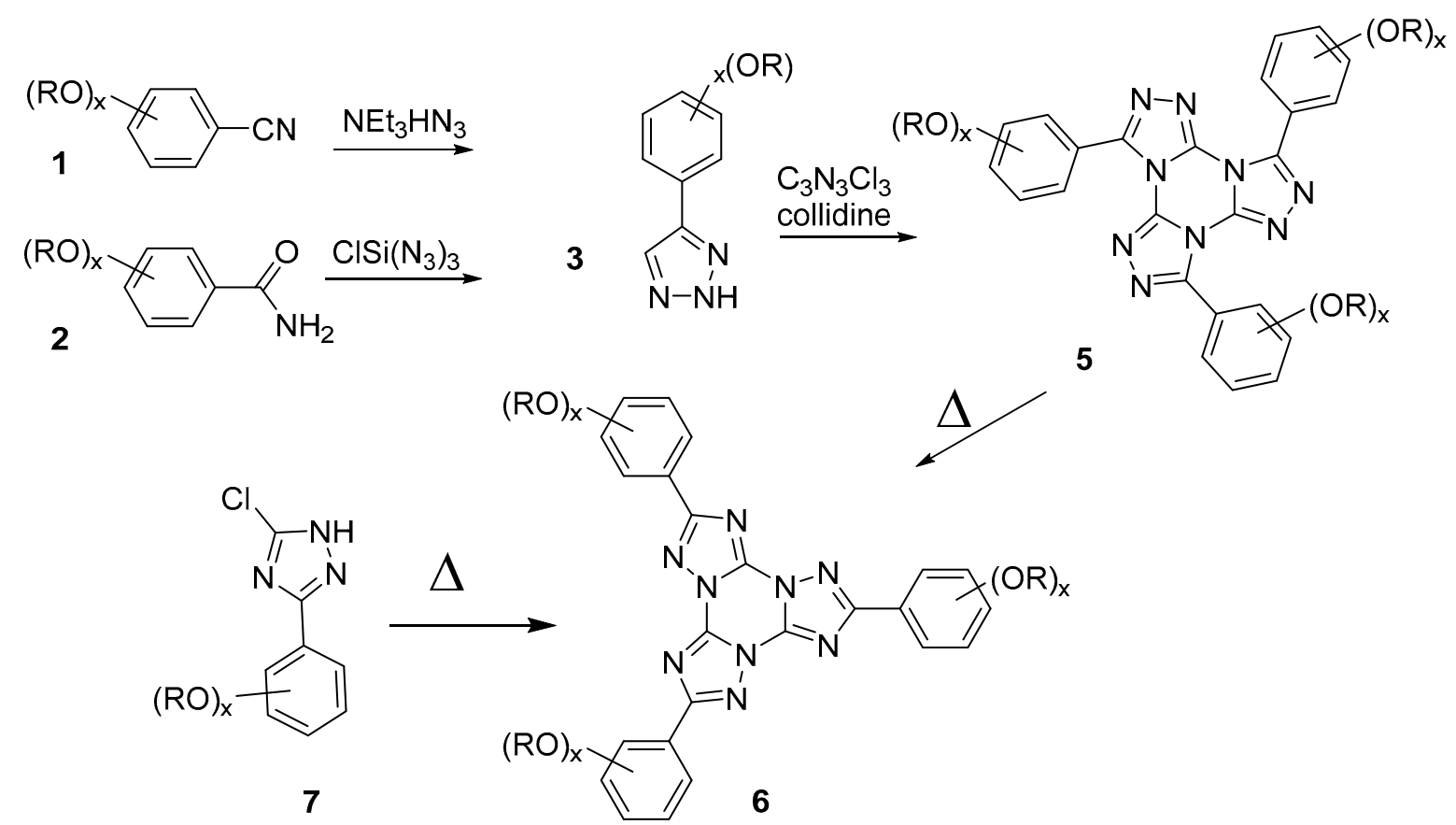

Scheme 1. Synthesis of $t$-TTTs and thermal rearrangement to $r$-TTTs.

\subsection{Thermal Properties of 1-n-alkyloxy-t-TTTs}

Some homologous series of $t$-TTTs with one to three linear alkyloxy were studied. Table 1 collects the TTTs together with their thermal characteristics. The order follows the substitution pattern (see Figure 1) and increasing chain length. Some compounds are reported in the literature, and the preparation and analytical data of new TTTs are provided in the Supporting Information (SI). Thermal properties were studied by differential scanning calorimetry (DSC) and polarized optical microscopy (POM), and structure determination of the mesophases was performed on representative compounds via X-ray diffraction (XRD). Details on equipment are given in the SI.

Table 1. Mono-, di- and tri-1-n-alkoxy $t$-TTTs and their thermal characteristics.

\begin{tabular}{|c|c|c|c|}
\hline Entry & Substitution Pattern & Transition $/{ }^{\circ} \mathrm{C}$ (Enthalpy $\left./ \mathrm{kJ} / \mathrm{mol}\right)$ & Ref \\
\hline$t-1$ & $\mathrm{R}^{\mathrm{i}}=\mathrm{H}$ & $\mathrm{Mp} .360^{\circ} \mathrm{C}$ & [56] \\
\hline$t-2$ & $\mathrm{R}^{4}=\mathrm{OC}_{3} \mathrm{H}_{7}$ & Mp. > 275 & [42] \\
\hline$t-3$ & $\mathrm{R}^{4}=\mathrm{OC}_{6} \mathrm{H}_{13}$ & Cr $129.9 \mathrm{I} ; \mathrm{T}_{\mathrm{g}}=55.4$ & [37] \\
\hline$t-4$ & $\mathrm{R}^{4}=\mathrm{OC}_{8} \mathrm{H} 1_{7}$ & $\operatorname{Cr} 93.8 \mathrm{I} ; \mathrm{T}_{\mathrm{g}}{ }^{\mathrm{C}}=46.7$ & SI \\
\hline$t-5$ & $\mathrm{R}^{4}=\mathrm{OC}_{10} \mathrm{H}_{21}$ & Cr 76 I & SI \\
\hline$t-6$ & $\mathrm{R}^{4}=\mathrm{OC}_{12} \mathrm{H}_{25}$ & $\mathrm{Cr} 86.8 \mathrm{I} ; \mathrm{T}_{\mathrm{g}}=36.7$ & SI \\
\hline$t-7$ & $\mathrm{R}^{4}=\mathrm{OC}_{13} \mathrm{H}_{27}$ & Cr $78 \mathrm{I}$ & SI \\
\hline$t-8$ & $\mathrm{R}^{3}=\mathrm{OC}_{10} \mathrm{H}_{21}$ & Cr 134 I & SI \\
\hline$t-9$ & $\mathrm{R}^{2}=\mathrm{OC}_{10} \mathrm{H}_{21}$ & $\mathrm{~T}_{\mathrm{g}}=-64 \mathrm{I}$ & SI \\
\hline$t-10$ & $\mathrm{R}^{2}=\mathrm{R}^{3}=\mathrm{OC}_{10} \mathrm{H}_{21}$ & Cr 69 I & SI \\
\hline$t-11$ & $\mathrm{R}^{2}=\mathrm{R}^{4}=\mathrm{OC}_{10} \mathrm{H}_{21}$ & Cr 50 I & SI \\
\hline
\end{tabular}


Table 1. Cont.

\begin{tabular}{|c|c|c|c|}
\hline Entry & Substitution Pattern & Transition $/{ }^{\circ} \mathrm{C}$ (Enthalpy/kJ/mol) & Ref \\
\hline$t-12$ & $\mathrm{R}^{2}=\mathrm{R}^{5}=\mathrm{OC}_{10} \mathrm{H}_{21}$ & Cr 89 I & SI \\
\hline$t-13$ & $\mathrm{R}^{3}=\mathrm{R}^{4}=\mathrm{OC}_{4} \mathrm{H}_{9}$ & Cr $131 \mathrm{I}$ & SI \\
\hline$t-14$ & $\mathrm{R}^{3}=\mathrm{R}^{4}=\mathrm{OC}_{5} \mathrm{H}_{11}$ & Cr 102 M 201 I & SI \\
\hline$t-15$ & $\mathrm{R}^{3}=\mathrm{R}^{4}=\mathrm{OC}_{6} \mathrm{H}_{13}$ & Cr 98 (21.0) M 232 (3.6) I & SI \\
\hline$t-16$ & $\mathrm{R}^{3}=\mathrm{R}^{4}=\mathrm{OC}_{7} \mathrm{H}_{15}$ & Cr 100 (22.7) M225 (4.7) I & SI \\
\hline$t-17$ & $\mathrm{R}^{3}=\mathrm{R}^{4}=\mathrm{OC}_{8} \mathrm{H}_{17}$ & Cr 100 (19.9) M 226 (4.5) I & [38] \\
\hline$t-18$ & $\mathrm{R}^{3}=\mathrm{R}^{4}=\mathrm{OC}_{9} \mathrm{H}_{19}$ & Cr 94 (19.8) M 215 (5.7) I & SI \\
\hline$t-19$ & $\mathrm{R}^{3}=\mathrm{R}^{4}=\mathrm{OC}_{10} \mathrm{H}_{21}$ & Cr 89 (14.3) Col hd 207 (6.7) I & [42] \\
\hline$t-20$ & $\mathrm{R}^{3}=\mathrm{R}^{4}=\mathrm{OC}_{11} \mathrm{H}_{23}$ & Cr 81 (5.7) M 200 (5.2) I & SI \\
\hline$t-21$ & $\mathrm{R}^{3}=\mathrm{R}^{4}=\mathrm{OC}_{12} \mathrm{H}_{25}$ & Cr 92.2 (19.3) Colh 207.6 (6.8) I & [42] \\
\hline$t-22$ & $\mathrm{R}^{3}=\mathrm{R}^{4}=\mathrm{OC}_{13} \mathrm{H}_{27}$ & Cr 74 (12.4) M 175 (6.1) I & SI \\
\hline$t-23$ & $\mathrm{R}^{3}=\mathrm{R}^{4}=\mathrm{OC}_{14} \mathrm{H}_{29}$ & $\mathrm{Cr}-11(46.3) \mathrm{M}_{2} 68$ (9.4) $\mathrm{M}_{1} 181$ (5.4) I & [42] \\
\hline$t-24$ & $\mathrm{R}^{3}=\mathrm{R}^{4}=\mathrm{OC}_{16} \mathrm{H}_{33}$ & Cr $19(58.7) \mathrm{M}_{2} 68$ (9.4) $\mathrm{M}_{1} 171$ (5.7) I & [42] \\
\hline$t-25$ & $\mathrm{R}^{3}=\mathrm{R}^{4}=\mathrm{OC}_{18} \mathrm{H}_{37}$ & Cr 40 (96.9) M 74 (9.1) $\mathrm{M}_{1} 164$ (7.5) I & SI \\
\hline$t-26$ & $\mathrm{R}^{3}=\mathrm{R}^{5}=\mathrm{OC}_{6} \mathrm{H}_{13}$ & Cr 136 M 187 I & [60] \\
\hline$t-27$ & $\mathrm{R}^{3}=\mathrm{R}^{5}=\mathrm{OC}_{7} \mathrm{H}_{15}$ & $\mathrm{Cr} 122 \mathrm{Col}_{\mathrm{h}} 179 \mathrm{I}$ & [60] \\
\hline$t-28$ & $\mathrm{R}^{3}=\mathrm{R}^{5}=\mathrm{OC}_{8} \mathrm{H}_{17}$ & Cr 92 M 152 I & [60] \\
\hline$t-29$ & $\mathrm{R}^{3}=\mathrm{R}^{5}=\mathrm{OC}_{10} \mathrm{H}_{21}$ & Cr 73 M 147 I & [60] \\
\hline$t-30$ & $\mathrm{R}^{3}=\mathrm{R}^{5}=\mathrm{OC}_{12} \mathrm{H}_{25}$ & Cr $74(6.8) \mathrm{Col}_{\mathrm{h}} 143(5.8) \mathrm{I}$ & [60] \\
\hline$t-31$ & $\mathrm{R}^{3}=\mathrm{R}^{5}=\mathrm{OC}_{12} \mathrm{H}_{25}, \mathrm{R}^{4}=\mathrm{Br}$ & Cr 58 (9.5) M 120 I & SI \\
\hline$t-32$ & $\mathrm{R}^{3}=\mathrm{R}^{5}=\mathrm{OC}_{16} \mathrm{H}_{33}$ & Cr 70 (7.4) M 115 (6.0) I & SI \\
\hline$t-33$ & $\mathrm{R}^{3}=\mathrm{R}^{4}=\mathrm{R}^{5}=\mathrm{OC}_{6} \mathrm{H}_{13}$ & Cr 116 (19.9) Col hd 184 (4.6) I & [37] \\
\hline$t-34$ & $\mathrm{R}^{3}=\mathrm{R}^{4}=\mathrm{R}^{5}=\mathrm{OC}_{8} \mathrm{H}_{17}$ & Cr 126 (22.8) Col hd 184 (5.6) I & [42] \\
\hline$t-35$ & $\mathrm{R}^{3}=\mathrm{R}^{4}=\mathrm{R}^{5}=\mathrm{OC}_{10} \mathrm{H}_{21}$ & Cr 126 (18.6) Colhd 165 (3.7) I & [42] \\
\hline$t-36$ & $\mathrm{R}^{3}=\mathrm{R}^{4}=\mathrm{R}^{5}=\mathrm{OC}_{12} \mathrm{H}_{25}$ & Cr 128 (22.7) Col hd 153 (6.9) I & SI \\
\hline$t-37$ & $\mathrm{R}^{3}=\mathrm{R}^{4}=\mathrm{R}^{5}=\mathrm{OC}_{16} \mathrm{H}_{33}$ & Cr 124 (24.6) M 144 (9.4) I & SI \\
\hline
\end{tabular}

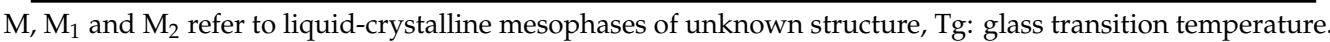

Triphenyl-t-TTT $\boldsymbol{t}$-1 is a sparingly soluble and high-melting compound $\left(360^{\circ} \mathrm{C}\right)$ [56]. Its $r$-isomer $r$-1 melts even higher: $390-400{ }^{\circ} \mathrm{C}$ [58]. The attachment of $p$-alkoxy chains significantly reduces the melting point $\left(t-2\right.$ : $\mathrm{O}-\mathrm{C}_{3} \mathrm{H}_{7}:>275{ }^{\circ} \mathrm{C}$ to $76{ }^{\circ} \mathrm{C}$ for $\mathrm{O}-\mathrm{C}_{10} \mathrm{H}_{21}(t-5)$, but $78{ }^{\circ} \mathrm{C}$ for $\left.\mathrm{O}-\mathrm{C}_{13} \mathrm{H}_{27}, t-7\right)$. Although these compounds are not mesomorphous, they can form stable glasses with $\mathrm{T}_{\mathrm{g}}$ in the range of $35-60{ }^{\circ} \mathrm{C}$ [1-4]. A comparison of the position of the alkyl chain, e.g., for decyloxy-t-TTTs, reveals a strong impact: whereas 4 -substituted TTT $t-5$ melts at $76{ }^{\circ} \mathrm{C}$, its 3 -isomer $t-8$ at $134{ }^{\circ} \mathrm{C}$ and the 2-isomer $t-9$ is a viscous oil SI. The steric effect of the ortho-alkoxy group, pointing into the center of the disks, is probably the reason for the lack of mesomorphism of TTTs with a 2,3-, 2,4- and 2,5-didecyloxy substitution $(\boldsymbol{t}-\mathbf{1 0}-\boldsymbol{t}$-12) SI. This appears to be valid even for TTTs with an extended $\pi$-system, e.g., $\boldsymbol{t}$-45 (Table 2).

The thermal behavior of 3,4-dialkoxyphenyl-substituted $t$-TTTs is completely different. This pattern is almost a warranty for mesomorphism (Table 1, Figure 2). The width of the mesophase is typically higher than $\Delta \mathrm{T}=100 \mathrm{~K}$ at a maximum of $192 \mathrm{~K}(t$-23). Although the 3,4-dibutoxy derivative melts at $132{ }^{\circ} \mathrm{C}$ without any sign of mesomorphism, the higher homologs from 3,4-dipentyloxy (t-14: Cr $102 \mathrm{M}$ $201 \mathrm{I})$, at least up to 3,4-dioctadecyloxy $\boldsymbol{t}$-25, are discotic liquid crystals ([38,42], SI). With increasing chain length, the clearing point successively drops from $232{ }^{\circ} \mathrm{C}$ (dihexyloxy, $t-16$ ) to $171{ }^{\circ} \mathrm{C}$ (dioctadecyloxy, $t$-28), and the melting points from $102{ }^{\circ} \mathrm{C}$ (dipentyloxy, $t$-14) to $74{ }^{\circ} \mathrm{C}$ (ditridecyloxy, $t$-22). Further chain elongation gives a surprising result. With the formation of an additional mesophase $\mathrm{M}_{2}$ (POM and DSC) below the typical LC range, e.g., with two tetradecyloxy chains $(\boldsymbol{t}$-23), the melting transition occurs at $-11{ }^{\circ} \mathrm{C}$ with an enthalpy of $46.3 \mathrm{~kJ} / \mathrm{mol}$ and an $\mathrm{M}_{2}-\mathrm{M}_{1}$ transition at $68^{\circ} \mathrm{C}(9.4 \mathrm{~kJ} / \mathrm{mol})$. This phase is stable up to $181^{\circ} \mathrm{C}(5.4 \mathrm{~kJ} / \mathrm{mol})$. Elongation of the side chains by two or four methylene groups $(t-24$, $t$-25) gives a similar phase behavior. Whereas the melting points increase significantly $\left(\mathrm{T}_{\mathrm{m}}=19^{\circ} \mathrm{C}\right.$; $\left.40{ }^{\circ} \mathrm{C}\right)$, the $\mathrm{M}_{2}-\mathrm{M}_{1}$ transition $\left(\mathrm{T}_{\mathrm{t}}=68^{\circ} \mathrm{C} ; 74{ }^{\circ} \mathrm{C}\right)$ and the clearing point are less affected $\left(\mathrm{T}_{\mathrm{C}}=181{ }^{\circ} \mathrm{C}\right.$; $171^{\circ} \mathrm{C}$ ). The phenomenon of the emergence of a second mesophase with increasing chain length has 
been observed earlier, e.g., with triphenylene hexaesters and hexabenzoates [44,45]. Both the TTT and triphenylene series have a columnar hexagonal structure of the upper LC phase in common. However, although the transitions from the first to second mesophase in the triphenylene series occur within the typical LC range, the additional mesomorphic phase of $t$-TTTs appears below this temperature regime.

Table 2. $t$-TTTs with extended p-systems and data from thermal analysis.

\begin{tabular}{|c|c|c|c|}
\hline Entry & Substitution Pattern & Transition $/{ }^{\circ} \mathrm{C}$ (Enthalpy/kJ/mol) & Ref \\
\hline$t-38$ & $6-\mathrm{OC}_{10} \mathrm{H}_{21}-\mathrm{Nap}[\mathrm{a}]$ & Cr $121 \mathrm{I}$ & SI \\
\hline$t-39$ & $5,6-\mathrm{OC}_{8} \mathrm{H}_{17}-\mathrm{Nap}[\mathrm{a}]$ & Cr 112 (1.3) Col $_{h}$ 197(2.6) I & {$[38]$} \\
\hline$t-40$ & $5,6-\mathrm{OC}_{10} \mathrm{H}_{21}$-Nap [a] & Cr 76 (7.6) M 210(2.3) I & SI \\
\hline$t-41$ & $5,6-\mathrm{OC}_{12} \mathrm{H}_{25}-\mathrm{Nap}[\mathrm{a}]$ & Cr 59 (1.5) $\mathrm{Col}_{\mathrm{h}} 189(2.9) \mathrm{I}$ & SI \\
\hline$t-42$ & $3^{\prime}, 4^{\prime}-\mathrm{OC}_{8} \mathrm{H}_{17}-\mathrm{Bip}[\mathrm{a}]$ & Cr 148 I & SI \\
\hline$t-43$ & $3^{\prime}, 4^{\prime}-\mathrm{OC}_{10} \mathrm{H}_{21}-\mathrm{Bip}[\mathrm{a}]$ & Cr 172 I & {$[38]$} \\
\hline$t-44$ & $3^{\prime}, 4^{\prime}-\mathrm{OC}_{12} \mathrm{H}_{25}-\mathrm{Bip}[\mathrm{a}]$ & Cr 89 (31.1) M 199 (2.6) I & SI \\
\hline$t-45$ & $2^{\prime}, 5^{\prime}-\left(\mathrm{OC}_{12} \mathrm{H}_{25}\right)_{2}-\mathrm{Bip}[\mathrm{a}]$ & Cr 87 I & SI \\
\hline$t-46$ & $4^{\prime}-\left(\mathrm{H}_{13} \mathrm{C}_{6} \mathrm{O}\right)_{2}-\mathrm{St}[\mathrm{a}]$ & $\mathrm{mp}>240$ & {$[37]$} \\
\hline$t-47$ & $3^{\prime}, 5^{\prime}-\left(\mathrm{H}_{13} \mathrm{C}_{6} \mathrm{O}\right)_{2}-\mathrm{St}[\mathrm{a}]$ & m.p. $124, \operatorname{Tg} 13$ & {$[37]$} \\
\hline$t-48$ & $3^{\prime}, 4^{\prime}, 5^{\prime}-\left(\mathrm{H}_{13} \mathrm{C}_{6} \mathrm{O}\right)_{2}-\mathrm{St}[\mathrm{a}]$ & Cr 175 M 200 I; Tg 178 & {$[37]$} \\
\hline$t-49$ & $4^{\prime}$-Нexo-PEP [a] & Cr 245 I & {$[4]$} \\
\hline$t-50$ & $3,4,5-\left(\mathrm{H}_{17} \mathrm{C}_{8} \mathrm{O}\right)_{3}$-PEP [a] & Cr 82 I & [4] \\
\hline$t-51$ & $3,4,5-\left(\mathrm{H}_{25} \mathrm{C}_{12} \mathrm{O}\right)_{3}-\mathrm{PEP}[\mathrm{a}]$ & Cr $80 \mathrm{I}$ & SI \\
\hline$t-52$ & 3,4,5-( $\left(\mathrm{H}_{17} \mathrm{C}_{8} \mathrm{O}\right)_{3}$-PEPEP [a] & Cr 159 M 204 I & {$[4]$} \\
\hline
\end{tabular}

[a] phenyl replaced by other aromatic unit; Nap = naphth-2-yl; Bip = biphenyl-4-yl; St = E-stilben-4-yl; PEPEP = 4-(4-phenylethynyl)-phenylethynyl)phenyl; Tg: glass transition temperature.

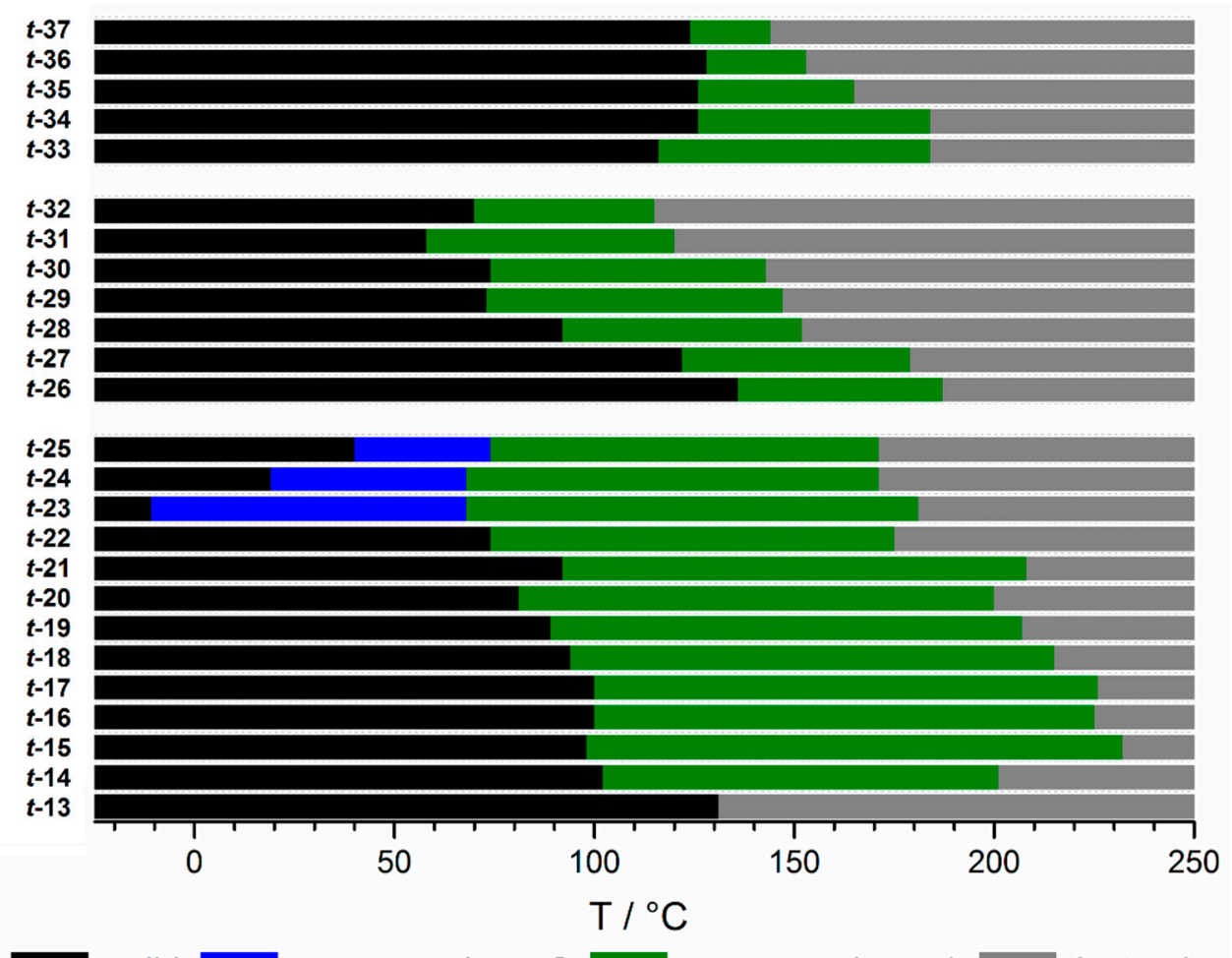

solid mesomorphous 2

mesomorphous 1

isotropic

Figure 2. Phase behavior of 3,4-di- $(\boldsymbol{t}$-13-t-25), 3,5-di- (t-26-t-32) and 3,4,5-trialkoxyphenyl $(t-33-t$-37)-substituted $t$-TTTs depending on chain length.

Miscibility of homologous $t$-TTTs allows the tuning of the phase transitions. Even a mixture of $25 \mathrm{~mol} \%$ of nonmesomorphous butoxy-TTT $\boldsymbol{t}$-13 and $75 \mathrm{~mol} \%$ decyloxy-substituted DLC $\boldsymbol{t}$-19 displays a LC phase Cr $75 \mathrm{M} 176$, only $\Delta \mathrm{T}=13 \mathrm{~K}$ lower and $\Delta \mathrm{T}=31 \mathrm{~K}$ narrower compared to pure $\boldsymbol{t} \mathbf{- 1 9 .}$ 
The series with the isomeric 3,5-dialkoxy pattern (t-26-t-32) [60] shows a more pronounced descent of phase transitions with increasing chain length ([60] SI). With decyl chains $t$-29, the melting point reaches a plateau at about $72{ }^{\circ} \mathrm{C}$. The width of the typically columnar hexagonal LC phase is about half as broad as found for the 3,4-isomers (Table 1, Figure 2). It increases from hexyl $t-26(\Delta \mathrm{T}=50 \mathrm{~K})$ to decyl $t-29(\Delta \mathrm{T}=74 \mathrm{~K})$ and decreases to $\Delta \mathrm{T}=45 \mathrm{~K}$ for hexadecyl $t$-32. An additional bromine atom between dodecyloxy chains $t$-31 reduces the melting point and slightly destabilizes the mesophase $(\Delta \mathrm{T}=62 \mathrm{~K}$ vs. $\Delta \mathrm{T}=68 \mathrm{~K}, \boldsymbol{t}-\mathbf{3 0}) \mathrm{SI}$. Adding a third alkoxy chain in the four-position of $t-30$ enhances the melting point and leads to the also mesomorphous tris(3,4,5-trialkoxyphenyl) $t$-TTTs, generally with a columnar hexagonal-disordered structure ([37,42], SI). Tris-(3,4,5-trihexyloxyphenyl) substitution $\left(t\right.$-33) gives rise to a broad mesophase $\left(\mathrm{Cr} 116 \mathrm{Col}_{\mathrm{hd}} 184 \mathrm{I}\right)[37,42]$. According to XRD, the hexagonal columnar phase has cell parameters of a $=25.5 \AA$ and $d=3.4 \AA$ at $20^{\circ} \mathrm{C}$ and in the mesophase at $145^{\circ} \mathrm{C}$. These values are $a=24.2 \AA$ and $\mathrm{d}=3.9 \AA$ at $20^{\circ} \mathrm{C}$. An ensemble of 16 molecules in a $2 a \times 2 a \times 4 c$ hexagonal supercell of $\boldsymbol{t}$-33 consisting of 16 unit cells was modeled with the program Accelrys Materials Studio 2017 R2 using the Compass2 force field [61]. In order to highlight the stabilization relative to 16 single mesogens, the energy differences were calculated for this model. As a result of the packing the valence energy increased by $500 \mathrm{kcal} / \mathrm{mol}$, but was opposed to an energy gain of $-1615 \mathrm{kcal} / \mathrm{mol}$ for the van der Waals and $-448 \mathrm{kcal} / \mathrm{mol}$ for the electrostatic energy. The stabilization by nonbonding intermolecular interactions was achieved by an offset of the cores from the center of the column. Figure 3 indicates that there is a tendency to locate the peripheral trialkoxy phenyl ring above the triazine center.

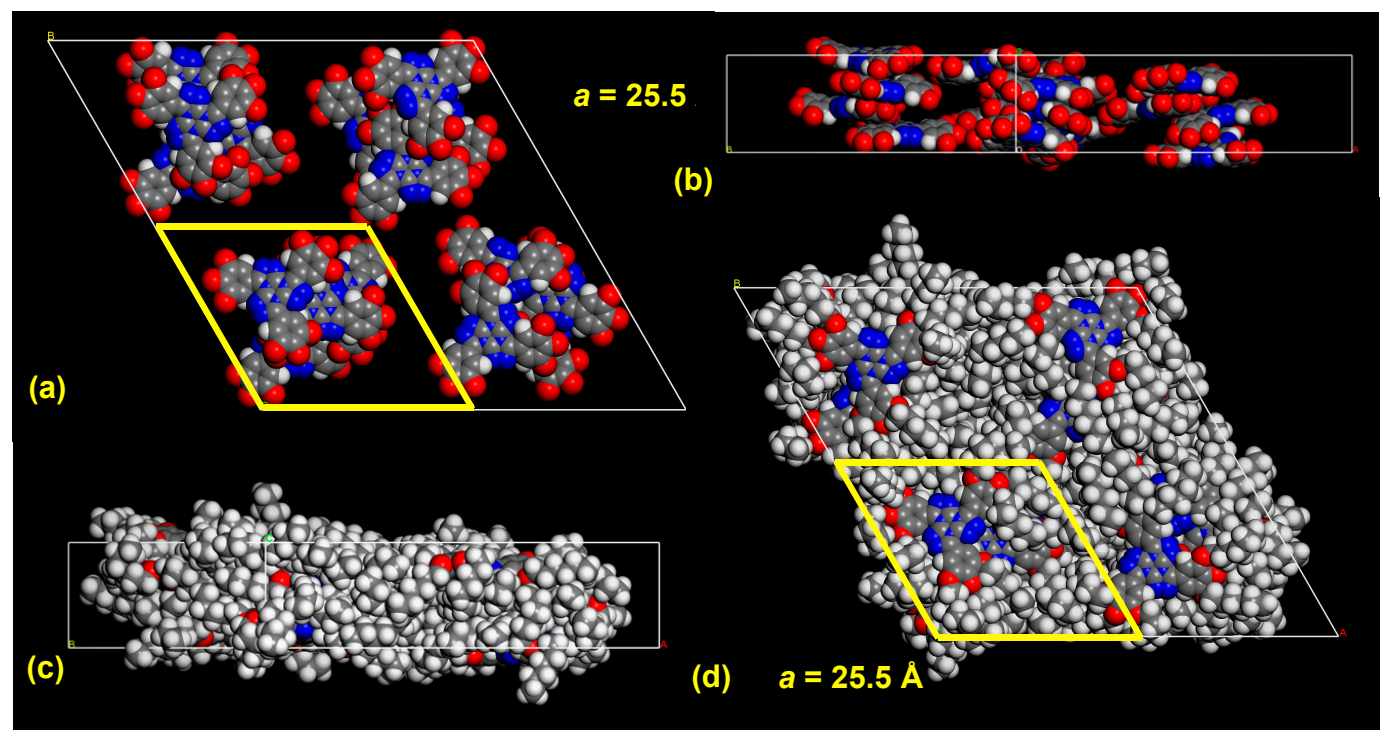

Figure 3. Model of a supercell $(2 a \times 2 a \times 4 c)$ of $\boldsymbol{t}$-33. (a,b) Top and side view, where hexyl chains are omitted; (c,d) side and top view, including hexyl chains.

Chain elongation raises the melting point to a plateau at ca. $126{ }^{\circ} \mathrm{C}$, but the width of the mesophase successively shrinks to $\Delta \mathrm{T}=20 \mathrm{~K}$ for hexadecyl chains $t$-37 due to decreasing clearing points. A comparison of the number of methylene groups in the periphery of TTTs reveals that 3,5-and 3,4,5-substituted TTTs with a similar molecular weight show a similar phase width, e.g., 3,5-dihexadecyl $\boldsymbol{t}$-32: $\Delta \mathrm{T}=39 \mathrm{~K}$ and 3,4,5-tri-decyl $\boldsymbol{t}$-35: $\Delta \mathrm{T}=45 \mathrm{~K}$ and 3,5-didodecyl $\boldsymbol{t}$-30: $\Delta \mathrm{T}=69 \mathrm{~K}$ and 3,4,5-tri-octyl $t$-34: $\Delta \mathrm{T}=58 \mathrm{~K}$. Cammidge reported that the exchange of a single hexyloxy chain on triphenylene DLC HAT6 versus bromine dilated the width of the LC phase by almost a factor of three [62]. A comparison of $t$-36 (Cr $128 \mathrm{Col} 153 \mathrm{I})$ and the didodecyloxy-bromo compound $\boldsymbol{t}$-31 (Cr $58 \mathrm{M}$ 120 I) gives a proportionate augmentation. Although the 3,5-pattern guarantees lower melting and clearing points, the "less symmetrical" 3,4-series gives the broadest mesophases. Hexagonal structures 
and $\pi$ - $\pi$-distances of about 3.48-3.8 $\AA$ are common features of the mesophases of the 3,4-, 3,5- and 3,4,5-substituted TTTs.

\subsection{Thermal Properties of t-TTTs with Extended $\pi$-Systems and a 1-n-alkyloxy Periphery}

TTTs with extended $\pi$-systems have been prepared as new materials for organic electronics, fluorophores and nonlinear optical materials. Like in the phenyl series, linear alkoxysubstitution can induce mesomorphism of TTTs with additional phenyl-, styryl- or phenylethynyl groups.

The distension of the rigid part by the elongation of the phenyl arms to naphthyl, biphenylyl, tolane or stilbene improves the $\pi-\pi$ interaction and heightens the melting points, e.g., $t-5-t-38$ (4-decyloxyphenyl-6-decyloxynaphthyl, $\Delta \mathrm{T}=+45 \mathrm{~K}$ ) and $\boldsymbol{t}$-3- $\boldsymbol{t}$-49 (4-hexyloxyphenyl-4'-hexyloxytolanyl, $\Delta \mathrm{T}=+115 \mathrm{~K})(\mathrm{SI})$. However, vicinal dialkoxy substitution in the lateral position is beneficial for the mesomorphism of 3,4-dialkoxyphenyl-t-TTTs ([38], SI); even after extension of the rigid part, naphthyl replacing phenyl, these disks form broad LC phases. From 5,6-di(octyloxy)naphth-2-yl $t$-39 to the dodecyl homolog $t-41$, the melting point drops from $112{ }^{\circ} \mathrm{C}$ to $59{ }^{\circ} \mathrm{C}$, and the $\mathrm{LC}$ phase widens from $85^{\circ} \mathrm{C}$ to $130^{\circ} \mathrm{C}$. $\boldsymbol{t}-\mathbf{4 1}$ forms a hexagonal mesophase with $a=30.8 \AA$ and a $\pi$ - $\pi$-distance of $3.6 \AA$ [38]. A further augmentation, naphth-2-yl to biphenyl-4-yl, destabilizes the LC phase, mainly due to enhanced melting points [38]. Although the $3^{\prime}, 4^{\prime}$-dioctyl and -decyl derivatives $t-42, t-43$ are not mesomorphic, dodecyl chains $t-44$ are sufficient for a broad LC phase from $\mathrm{T}=89^{\circ} \mathrm{C}$ to $198^{\circ} \mathrm{C}$. Further extension of the rigid part, stilbene $(t-47, t-48)$, tolane $(t-50, t-51)$ and phenylethynyltolane $(t-52)$ replacing phenyl can give DLCs ([4,37] SI). Whereas 3,5-dihexyloxy is insufficient for mesomorphism of stilbene derivative $t$-47, the 3,4,5-trihexyloxy periphery $\boldsymbol{t}$-48 results in a narrow mesophase at high temperatures $(\mathrm{Cr} 175 \mathrm{M}$ $200 \mathrm{I})$. This pattern with slightly longer octyl chains allows mesomorphism even of the extended phenylethynyltolane TTT $\boldsymbol{t}$-52 (Cr 159 M $204 \mathrm{I})$. POM suggests a discotic nematic structure for the $45 \mathrm{~K}$ broad LC phase. The shorter homologs with tolane units and three octyl or dodecyl chains, $t-50 t-51$, have nearly identical melting points $\left(82{ }^{\circ} \mathrm{C}, 80^{\circ} \mathrm{C}\right)$, about $\Delta \mathrm{T} \approx 45 \mathrm{~K}$ lower than their phenyl homologs $t-34, t-36$. Unfortunately, the tolane derivatives are not mesomorphous.

\subsection{Thermal Properties of t-TTTs with Branched Side Chains, Swallow-Tails or Chains of Different Lengths}

Chain branching is another useful concept to modify the thermal properties of calamitic and discotic liquid crystals. This approach is particularly useful to reduce melting and clearing points, notably for large-core mesogens [63-71]. Two different strategies are applied: short-chain branching [35,36,72-79] like 3,7-dimethyloctyl or 2-ethylhexyl and Weissflogs swallow-tails [80-85].

Short-chain branching has a strong impact on thermal properties, even on nonmesomorphous 4-alkoxyphenyl-TTTs (Table 3). Although $p$-decyloxy TTT $t-5$ melts at $76{ }^{\circ} \mathrm{C}$, the diastereotopic mixture of the $p$-(3,7-dimethyloctyloxy) derivative $t$-53 is a viscous oil. (SI) On the other hand, $t$-54, with a voluminous but rigid neomenthyloxy periphery, is crystalline up to $185^{\circ} \mathrm{C}$; if the voids in the crystal are filled with suitable solvent molecules, the crystal phase is stable up to $211^{\circ} \mathrm{C}$ [41]. Short-chain branching has a similar effect in the 3,4-dialkoxy series: change from n-octyloxy $\left(t-17, \mathrm{~T}_{\mathrm{C}}=223^{\circ} \mathrm{C}\right)$ to 3-octyloxy $\left(t-55, \mathrm{~T}_{\mathrm{c}}=158^{\circ} \mathrm{C}\right)$ or 2-ethylhexyloxy $\left(t-56, \mathrm{~T}_{\mathrm{C}}=157^{\circ} \mathrm{C}\right)$ provokes depression of the clearing point of nearly $\Delta \mathrm{T}=70 \mathrm{~K}$ and even more of melting points. Concerning longer chains, the impact of branching is leveled. Relative to the linear 3,4-didecyloxy TTT $\left(t-29, \mathrm{~T}_{\mathrm{C}}=207^{\circ} \mathrm{C}\right)$, clearing of 4-ethyloctyl-, as well as the 3,7-dimethyloctyl analog $t-57, t-58$ is reduced to $T_{\mathrm{C}}=182^{\circ} \mathrm{C}$ (SI) for $t-59$ with enantiopure (R)-citronellyl chains $\mathrm{T}_{\mathrm{C}}=167^{\circ} \mathrm{C}$ [1]. Laschat reported a beneficial effect on the phase width of short-chain branching in the $\delta$-position on triphenylene systems [76]. Unfortunately, this cannot be generalized since the 3,4,5-trialkoxy derivatives $t-34, t-35$ are mesomorphous, the branched isomers $\boldsymbol{t}-\mathbf{6 1}, \boldsymbol{t}-\mathbf{6 2}$ are not (SI). The LC phase of $\boldsymbol{t}-\mathbf{6 0}$ with the nonchiral and more rigid 3,3-dimethyloctyl chains is stable only until $154^{\circ} \mathrm{C}$ and crystallization occurs on the timescale of months (first heating: $\mathrm{T}_{\mathrm{m}}=56^{\circ} \mathrm{C}$; $\mathrm{T}_{\mathrm{g}}=8^{\circ} \mathrm{C}$ ). Depending on the cooling rate, POM textures either show a homeotropic growth or fan structure (Figure 4). 
Table 3. $t$-TTTs with branched chains, swallow-tails and mixed-chain lengths, and data from thermal analysis.

\begin{tabular}{|c|c|c|c|}
\hline Entry & Substitution Pattern & Transition $/{ }^{\circ} \mathrm{C}$ (Enthalpy/kJ/mol) & Ref \\
\hline$t-53$ & $\mathrm{R}^{4}=\mathrm{O}\left(\mathrm{CH}_{2}\right)_{2} \mathrm{CH}\left(\mathrm{CH}_{3}\right)\left(\mathrm{CH}_{2}\right)_{3} \mathrm{CH}\left(\mathrm{CH}_{3}\right)_{2}$ & I & SI \\
\hline$t-54$ & $\mathrm{R}^{4}=$ neomenthyloxy & Cr 185 I & [41] \\
\hline$t-55$ & $\mathrm{R}^{3}=\mathrm{R}^{4}=\mathrm{O}-\mathrm{CH}\left(\mathrm{C}_{2} \mathrm{H}_{5}\right) \mathrm{C}_{5} \mathrm{H}_{11}$ & $\mathrm{Col}_{\mathrm{h}} 158 \mathrm{I}$ & [1] \\
\hline$t-56$ & $\mathrm{R}^{3}=\mathrm{R}^{4}=\mathrm{O}-\mathrm{CH}_{2} \mathrm{CH}\left(\mathrm{C}_{2} \mathrm{H}_{5}\right) \mathrm{C}_{4} \mathrm{H}_{9}$ & $\mathrm{Cr}-9 \mathrm{M} 157 \mathrm{I}$ & SI \\
\hline$t-57$ & $\mathrm{R}^{3}=\mathrm{R}^{4}=\mathrm{O}-\left(\mathrm{CH}_{2}\right)_{3} \mathrm{CH}\left(\mathrm{C}_{2} \mathrm{H}_{5}\right) \mathrm{C}_{4} \mathrm{H}_{9}$ & Cr72 (15.8) M 182 (5.7) & SI \\
\hline$t-58$ & $\mathrm{R}^{3}=\mathrm{R}^{4}=\mathrm{O}\left(\mathrm{CH}_{2}\right)_{2} \mathrm{CH}\left(\mathrm{CH}_{3}\right)\left(\mathrm{CH}_{2}\right)_{3} \mathrm{CH}\left(\mathrm{CH}_{3}\right)_{2}$ & Cr (51) M 182 (5.8) I & SI \\
\hline$t-59$ & $\mathrm{R}^{3}=\mathrm{R}^{4}=(\mathrm{R})-\mathrm{O}\left(\mathrm{CH}_{2}\right)_{2} \mathrm{CH}\left(\mathrm{CH}_{3}\right)-\left(\mathrm{CH}_{2}\right)_{2} \mathrm{CH}=\mathrm{C}\left(\mathrm{CH}_{3}\right)_{2}$ & $\mathrm{Cr} 41 \mathrm{Col}_{\mathrm{h}} 167 \mathrm{I}$ & [1] \\
\hline$t-60$ & $\mathrm{R}^{3}=\mathrm{R}^{4}=\mathrm{O}\left(\mathrm{CH}_{2}\right)_{2} \mathrm{C}\left(\mathrm{CH}_{3}\right)_{2} \mathrm{C}_{5} \mathrm{H}_{11}$ & Cr 56 (17.4) Col 154 (4.6) I ( $\left.\mathrm{T}_{\mathrm{g}} 8\right)$ & SI \\
\hline$t-61$ & $\mathrm{R}^{3}=\mathrm{R}^{4}=\mathrm{R}^{5}=\mathrm{O}-\mathrm{CH}_{2}-\mathrm{CH}\left(\mathrm{C}_{2} \mathrm{H}_{5}\right) \mathrm{C}_{4} \mathrm{H}_{9}$ & Cr 160 I [a] & SI \\
\hline$t-62$ & $\mathrm{R}^{3}=\mathrm{R}^{4}=\mathrm{R}^{5}=\mathrm{O}-\left(\mathrm{CH}_{2}\right)_{3} \mathrm{CH}\left(\mathrm{C}_{2} \mathrm{H}_{5}\right) \mathrm{C}_{4} \mathrm{H}_{9}$ & Cr 124 I & [42] \\
\hline$t-63$ & $\mathrm{R}^{3}=\mathrm{OCH}_{2} \mathrm{CH}\left(\mathrm{C}_{8} \mathrm{H}_{17}\right)_{2}$ & $-64\left(\mathrm{~T}_{\mathrm{g}}\right) \mathrm{I}$ & SI \\
\hline$t-64$ & $\mathrm{R}^{4}=\mathrm{OCH}_{2} \mathrm{CH}\left(\mathrm{C}_{6} \mathrm{H}_{13}\right)_{2}$ & $14\left(\mathrm{~T}_{\mathrm{g}}\right) \mathrm{Col}_{\mathrm{h}} 65 \mathrm{I}$ & SI \\
\hline$t-65$ & $\mathrm{R}^{4}=\mathrm{OCH}_{2} \mathrm{CH}\left(\mathrm{C}_{8} \mathrm{H}_{17}\right)_{2}$ & $\mathrm{Cr}-15(2.1) \mathrm{M} 101$ (2.1) I & SI \\
\hline$t-66$ & $\mathrm{R}^{4}=\mathrm{OCH}_{2} \mathrm{CH}\left(\mathrm{C}_{10} \mathrm{H}_{21}\right)_{2}$ & $\mathrm{Cr}-70 \mathrm{Tg} 9 \mathrm{Tg} \mathrm{Col}_{\mathrm{h}} 85(2,0) \mathrm{I}$ & SI \\
\hline$t-67$ & $\mathrm{R}^{4}=\mathrm{OCH}_{2} \mathrm{CH}\left(\mathrm{C}_{12} \mathrm{H}_{25}\right)_{2}$ & $\mathrm{Cr}-54(19.5) \mathrm{Col}_{\mathrm{h}} 82(2.4) \mathrm{I}$ & SI \\
\hline$t-68$ & $\mathrm{R}^{4}=\mathrm{OCH}\left(\mathrm{C}_{6} \mathrm{H}_{13}\right)$ & $\mathrm{Cr} 8(1.6) \mathrm{I}$ & SI \\
\hline$t-69$ & $\mathrm{R}^{4}=\mathrm{O}\left(\mathrm{CH}_{2}\right)_{2} \mathrm{CH}\left(\mathrm{C}_{6} \mathrm{H}_{13}\right)$ & $\mathrm{Cr}-71 \mathrm{I}$ & SI \\
\hline$t-70$ & $\mathrm{R}^{4}=\mathrm{OCH}_{2} \mathrm{CH}\left(\left(\mathrm{CH}_{2}\right)_{2} \mathrm{CH}\left(\mathrm{CH}_{3}\right)_{2}\right)_{2}$ & $\mathrm{~T}_{\mathrm{g}}=42 \mathrm{~T}_{\mathrm{m}}=47$ & SI \\
\hline$t-71$ & $\mathrm{R}^{4}=\mathrm{O}-\mathrm{CH}_{2} \mathrm{CH}\left(\mathrm{CH}_{2} \mathrm{CH}\left(\mathrm{C}_{2} \mathrm{H}_{5}\right) \mathrm{C}_{4} \mathrm{H}_{9}\right)_{2}$ & Cr 95 (7.1) M 140 I [b] POM: 80-120 & SI \\
\hline$t-72$ & $\mathrm{R}^{3}=\mathrm{R}^{4}=\mathrm{OCH}_{2} \mathrm{CH}\left(\mathrm{C}_{6} \mathrm{H}_{13}\right)_{2}$ & Cr 86 I & SI \\
\hline$t-73$ & $\mathrm{R}^{3}=\mathrm{OC}_{4} \mathrm{H}_{9}, \mathrm{R}^{5}=\mathrm{OC}_{16} \mathrm{H}_{33}$ & $47\left(\mathrm{~T}_{\mathrm{g}}\right) \mathrm{M} 91(2.1) \mathrm{I}$ & SI \\
\hline$t-74$ & $\mathrm{R}^{3}=\mathrm{OC}_{6} \mathrm{H}_{13}, \mathrm{R}^{5}=\mathrm{OC}_{14} \mathrm{H}_{29}$ & Cr 59 M $132(4.5) \mathrm{I}$ & SI \\
\hline$t-75$ & $\mathrm{R}^{3}=\mathrm{OC}_{16} \mathrm{H}_{33}, \mathrm{R}^{4}=\mathrm{OCH}_{3}$ & Cr 98 I & SI \\
\hline$t-76$ & $\mathrm{R}^{3}=\mathrm{OC}_{14} \mathrm{H}_{29}, \mathrm{R}^{4}=\mathrm{OC}_{6} \mathrm{H}_{13}$ & Cr 103 (23.0) M 183 (4.0) I & SI \\
\hline$t-77$ & $\mathrm{R}^{3}=\mathrm{COOC}_{10} \mathrm{H}_{21}, \mathrm{R}^{4}=\mathrm{OC}_{10} \mathrm{H}_{21}$ & $\mathrm{Cr}_{1} 61(6.0) \mathrm{Cr}_{2} 89$ (5.3) I & SI \\
\hline$t-78$ & $\mathrm{R}^{3}=\mathrm{R}^{4}=\mathrm{OC}_{6} \mathrm{H}_{13}, \mathrm{R}^{5}=\mathrm{OC}_{12} \mathrm{H}_{25}$ & Cr 127 (21.4) M 158 (4.9) I & SI \\
\hline$t-79$ & $\mathrm{R}^{3}=\mathrm{R}^{4}=\mathrm{OC}_{6} \mathrm{H}_{13}, \mathrm{R}^{5}=\mathrm{O}-\left(\mathrm{CH}_{2}\right)_{3} \mathrm{CH}\left(\mathrm{C}_{2} \mathrm{H}_{5}\right) \mathrm{C}_{4} \mathrm{H}_{9}$ & $\mathrm{Cr} 80(23.8) \mathrm{Col}_{\mathrm{h}} 136(1.5) \mathrm{I}$ & SI \\
\hline
\end{tabular}

[a] determined by POM; Tg: glass transition temperature; [b] values from 1, heating scan.

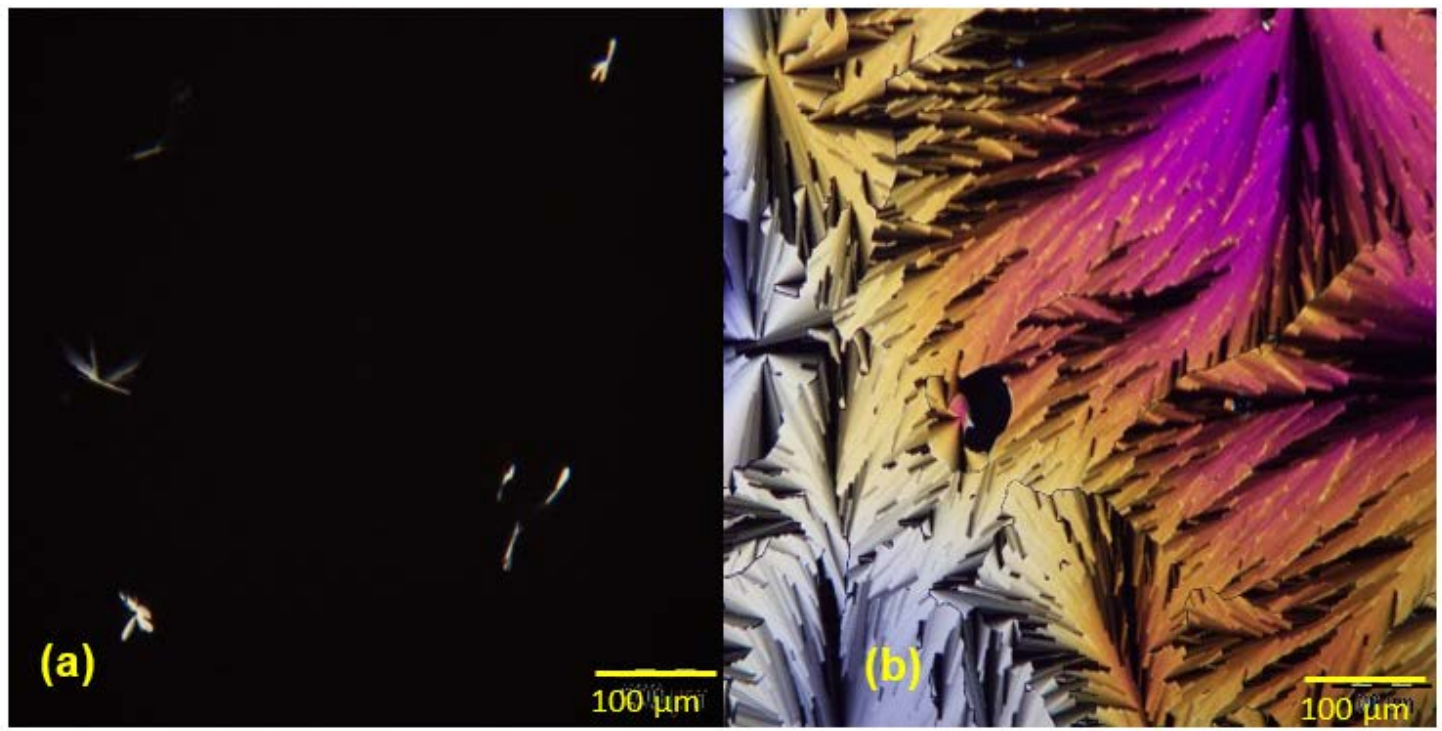

Figure 4. (a): Homeotropic growth of $\boldsymbol{t}-60$ at $135^{\circ} \mathrm{C}$ (cooling rate: $\left.1{ }^{\circ} \mathrm{C} / \mathrm{min}\right) ;(\mathbf{b})$ : fan textures at $137^{\circ} \mathrm{C}$ (cooling rate: $1^{\circ} \mathrm{C} / \mathrm{min}$ ).

The XRD (SI) results reveal a hexagonal columnar mesophase of $\boldsymbol{t}-60$. The structure is retained in the solid phase, but the lattice constants increase $\left(130{ }^{\circ} \mathrm{C}: a_{\mathrm{hex}}=27.0 \AA ; 25^{\circ} \mathrm{C}: a_{\mathrm{hex}}=27.8 \AA\right)$. It should be noted that this lattice constant is larger than of the compound with the linear chain (3,4-O-decyloxy $t$-19: $\left.a_{\text {hex }}=26.2 \AA\left(20^{\circ} \mathrm{C}\right) 26.8 \AA\left(145^{\circ} \mathrm{C}\right)\right)$, which can be attributed to the Thorpe-Ingold effect, preventing 
the alkyl chains from interdigitation. The experimental $(1.02 \mathrm{~g} / \mathrm{mL})$ and X-ray density $(0.99 \mathrm{~g} / \mathrm{mL})$ are nearly identical, and the $\pi$ - $\pi$-distance in $t-60$ is assumed to correspond to $d=3.4 \AA\left(25^{\circ} \mathrm{C}\right)$. This accounts for a single molecule per unit cell. The correlation length at $25^{\circ} \mathrm{C}$ is $15-18$ molecules. A simulation using Materials Studio [61] gives stacks of molecules twisted about $60^{\circ}$. These columns are arranged in a hexagonal superstructure with a lattice constant a $=27.8 \AA$. (Figure 5). The self-assembly of 16 molecules in a supercell analogous to $t-33$ was geometry optimized (Figure 5). As a result of the packing, the valence energy increases by $370 \mathrm{kcal} / \mathrm{mol}$ while the intermolecular energy gain amounts to $-1607 \mathrm{kcal} / \mathrm{mol}$ for the van der Waals and $-392 \mathrm{kcal} / \mathrm{mol}$ for the electrostatic interaction. This stabilization of the derivatives with the branched chains is also achieved by an offset of the cores from the center of the column and a tendency to locate the peripheral dialkoxy phenyl ring above the triazine centers.

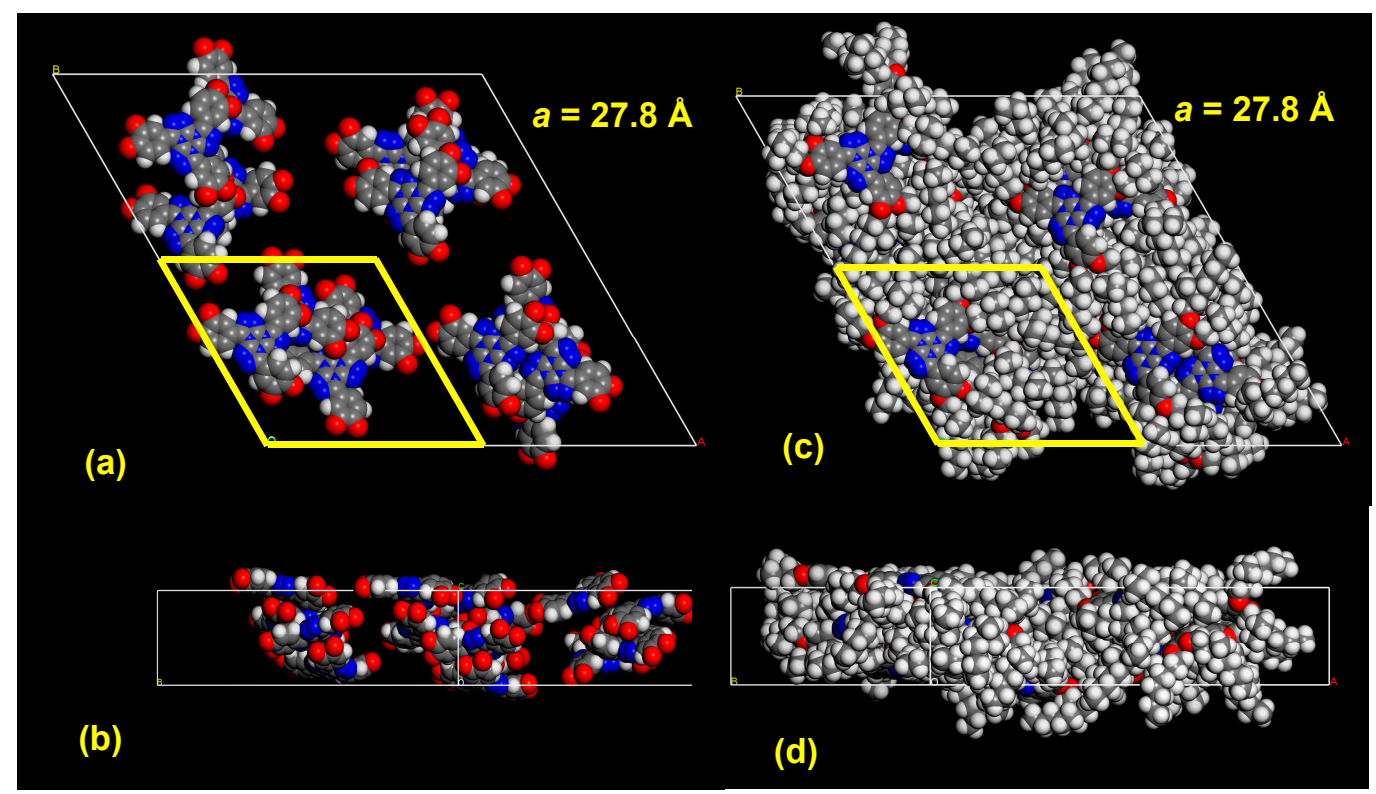

Figure 5. Modeled liquid crystal (LC) phase of $t-60$ : $(\mathbf{a}, \mathbf{b})$ : top and side view on columns in the c-direction, where alkyl chains are omitted; $(\mathbf{c}, \mathbf{d})$ top and side view.

If the rim of the TTT carries three branched 4-ethyloctyloxy chains per phenyl unit ( $t$-62) [42], the melting point of $\mathrm{T}_{\mathrm{m}}=124{ }^{\circ} \mathrm{C}$ matches that of the analog with linear decyl chains $(t-35$ : $\mathrm{Cr} 126$ $\mathrm{Col}_{\text {hd }} 165 \mathrm{I}$ ), but mesomorphism is erased. Diasteromerism appears to be of minor importance for LC properties. The phase width of the compound with chiral citronellyloxy chains [2] ( $t$-59: $\mathrm{Cr} 41 \mathrm{Col}_{\mathrm{h}}$ $167 \mathrm{I})$ is comparable to the TTT prepared from a racemic mixture of 3,7-dimethyloctyl chains ( $t$-58: Cr 51 M 182 I) (SI), but with the difference that the latter refrains from crystallization within the timescale of a DSC experiment. It appears that branching, e.g., the exchange of decyl to 3,7-dimethyloctyl has a comparable but more pronounced impact on TTTs as on triphenylenes $[44,86]$.

Swallow-tail side chains are readily accessible via twofold malonester alkylation followed by decarboxylation and reduction. They offer a successful strategy to greatly enhance the solubility of large-core DLCs and generate mesomorphism in these materials [63-71]; their effect on thermal properties is expected to correlate with that of twofold alkylation with linear chains of similar length. Several $p$-alkoxyphenyl-t-TTTs $(\boldsymbol{t}$-64-t-71) with swallow-tails are investigated. The typical "2,2-dialkylethyl" with alkyl equals hexyl to dodecyl are complimented by swallow-tails with additional branching in the alkyl unit and by tails with the systematic variation of the branching position (SI). para-Substitution with 2,2-dihexylethyl (2-hexyloct-1-yl) results in a mesomorphous material $t$-64 with $\mathrm{T}_{\mathrm{C}}=65{ }^{\circ} \mathrm{C}$. DSC reveals only a glass transition at $14{ }^{\circ} \mathrm{C}$. The higher homolog $t-65$ (2,2-dioctylethyl) displays a room-temperature LC phase with $\mathrm{T}_{\mathrm{m}}=-15{ }^{\circ} \mathrm{C}(\Delta \mathrm{H}=2.1 \mathrm{~kJ} / \mathrm{mol})$ and $\mathrm{T}_{\mathrm{C}}=101{ }^{\circ} \mathrm{C}$ $(\Delta \mathrm{H}=2.1 \mathrm{~kJ} / \mathrm{mol})$. The low-melting enthalpy of a pristine sample indicates incomplete crystallization; 
in subsequent experiments, no crystallization or melting was observed. The width of the LC phase $(116 \mathrm{~K})$ is nearly as large as 3,4-dinonyloxy- and 3,4-didecyloxy-TTTs $\boldsymbol{t}$-18, $\boldsymbol{t}$-19 with a similar number of atoms in the chains ( $\Delta \mathrm{T}$ ca. $120 \mathrm{~K})$, but the transitions appear at significantly lower temperatures $(\Delta \mathrm{T}$ ca. $-100 \mathrm{~K})$. Further extension of the chains ( $\boldsymbol{t}$-66: $p$-2,2-didecylethyl, $\boldsymbol{t}$-67: $p$-2,2-didodecylethyl) also gives room-temperature DLCs with lower $\mathrm{T}_{\mathrm{C}}\left(85^{\circ} \mathrm{C}, 82^{\circ} \mathrm{C}\right)$ and even lower $\mathrm{T}_{\mathrm{m}}\left(-70{ }^{\circ} \mathrm{C},-54{ }^{\circ} \mathrm{C}\right)$ (SI). The structure of these phases is columnar hexagonal (XRD), and POM textures strongly depend on the cooling rate and film thickness (Figure 6).

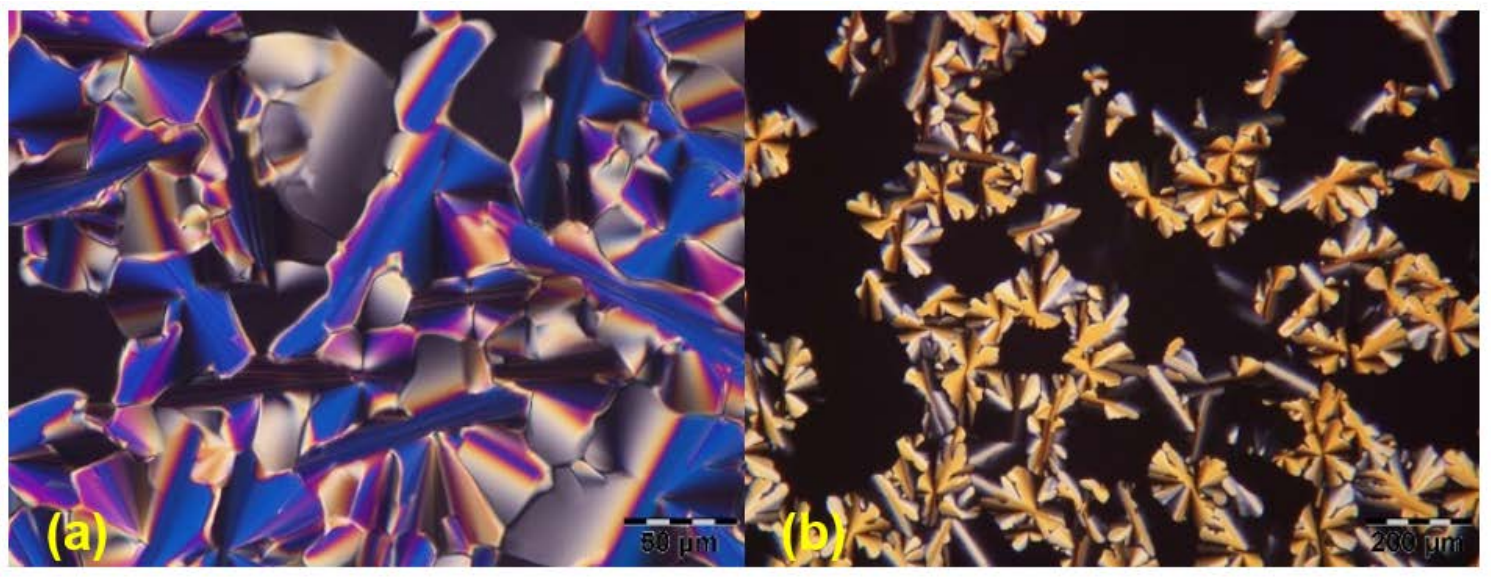

Figure 6. POM of $t$-66: (a): at $84^{\circ} \mathrm{C}$; (b): fan and homeotropic orientation at $65^{\circ} \mathrm{C}$.

The mesophase of $\boldsymbol{t}$-66 has a hexagonal columnar structure with $a_{\text {hex }}=30.78 \AA$. Slightly decreasing with increasing temperature, the $\pi-\pi$ distance is $3.58 \AA$. This and the aberration of X-ray density $(0.79 \mathrm{~g} / \mathrm{mL})$ from the measured density $(0.97 \mathrm{~g} / \mathrm{mL})$ enforced a new model for the structure. For comparison, the lattice constants of the similar 3,4-didecyloxy $t$-19 $\left(a_{\text {hex }}=26.2 \AA\right)$ and didodecyloxy $\boldsymbol{t}$-21 $\left(a_{\text {hex }}=30.4 \AA\right)$ are significantly lower. The X-ray diffractogram of $\boldsymbol{t}$-66 is also in accordance with a hexagonal lattice with $a=30.78 \AA$ and $c=5.85 \AA$. These parameters result in a density of $0.97 \AA$. A simulation [24] leads to two contorted molecules per unit cell, allowing a $\pi-\pi$ distance of $3.58 \AA$ and $\mathrm{a}_{\mathrm{hex}}=30.8$. $\AA$. This model and the X-ray reflections give a correlation length of $<20 \AA$ (Figure 7).

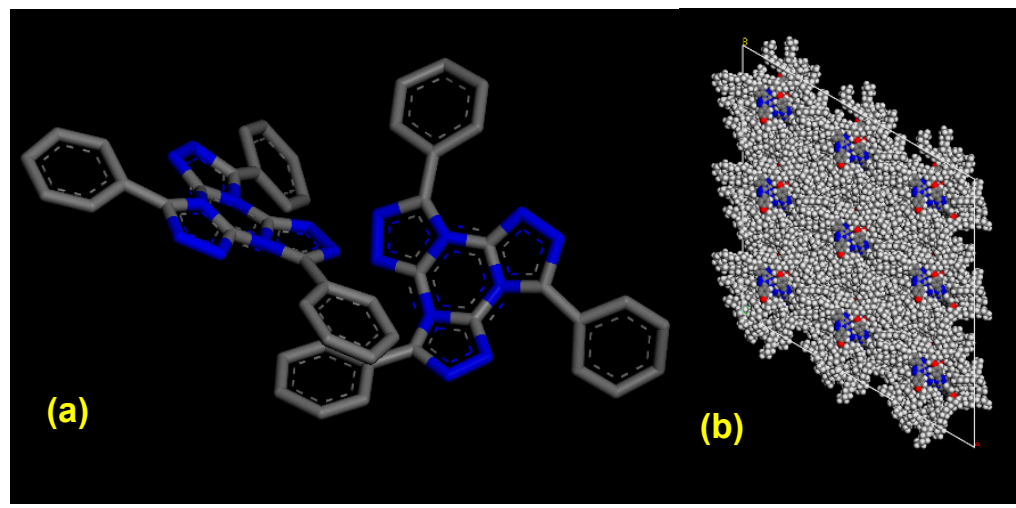

Figure 7. (a) Simulated structure of $\boldsymbol{t}$-66: aromatic part of dimer; (b) view on $3 \times 3 \times 6$ unit cells.

The series of related $p$-swallowtail $t$-TTTs with 1-hexylheptyloxy ( $\boldsymbol{t}$-68: $\mathrm{Cr} 8 \mathrm{I})$, 2-hexyloctyloxy $(\boldsymbol{t}$-64: $\left.\mathrm{T}_{\mathrm{g}} 14 \mathrm{M} 65 \mathrm{I}\right)$ and 3-hexylnonyloxy ( $\boldsymbol{t}-\mathbf{6 1}$ : $\left.\mathrm{Cr}-71 \mathrm{I}\right)$ shows the strong impact of the branching position on the thermal properties. Whereas the LC behavior of these low-melting compounds is severely restricted, 3,4-disubstituted $t$-TTTs $\boldsymbol{t}$-16 and $\boldsymbol{t}$-17 of similar mass are LCs with broad mesophases above $100{ }^{\circ} \mathrm{C}$. Additional branching in the swallow-tail destabilizes the LC phase; the $p$-(diisoamyl)ethyloxy t-70 TTT 
is nonmesomorphous (SI). Although the diastereomeric $p$-2,2-di(2-ethylhexyl)ethyloxy derivative $\boldsymbol{t}$-71 is a LC with Cr 95 M 140 I, its isomer $\boldsymbol{t}$-65 without additional branching, 2-octyldecyloxy, is characterized by $\mathrm{Cr}-15 \mathrm{M} 101 \mathrm{I}$ (SI). Likewise, $\boldsymbol{t}$-72 with two branched chains (3,4-di(2-hexyloctyl)) melts at $86^{\circ} \mathrm{C}$ without any sign of mesomorphism, whereas the isomer $t-23$ with two linear tetradecyl chains is a LC with a phase width of $192 \mathrm{~K}$. Excessive branching reduces the conformational freedom in the aliphatic chains.

Discotic liquid crystals with alkoxy chains of different lengths appear only scarcely [87-93]. All compounds above are TTTs with three to nine peripheral chains of identical length in each case, linear or branched. Three series of TTTs with different chains on the phenyl substituent were prepared: compounds with a 3,4-3,5- and 3,4,5-di/tri-alkoxy pattern (SI). For example, 3,5-dialkoxy-substituted DLCs with either 3-butoxy-5-hexadecyloxy ( $t$-73: 47( $\left.\mathrm{T}_{\mathrm{g}}\right) \mathrm{M}$ 91(2.1) I) periphery or 3-hexyloxy-5-tetradecyloxy substitution (t-74: $\mathrm{Cr} 59 \mathrm{Col}_{(\text {hex?) }} 123$ (4.5) I) are isomers of $\boldsymbol{t}$-29 (3,5-didecyloxy, Cr 73 M 147 I). The reduced symmetry has a strong impact on the thermal properties; the more unbalanced the periphery, the lower appear the transitions $\left(\mathrm{T}_{\mathrm{m}}, \mathrm{T}_{\mathrm{c}}\right)$. Since the melting point is not as decreased as the clearing point, the width of the mesophase shrinks with the imbalanced chain length.

Accordingly, a 3-hexadexyloxy-4-methoxy periphery $(t-75: \quad C r 98 \mathrm{I})$ is not sufficient for mesomorphism, but 3-tetradecyloxy-4-hexyloxy gives a broad mesophase ( $t$-76: Cr103 M 183 I). It is interesting that the melting point corresponds to the m.p. of the dihexyloxy derivative $(t-15$ : $\left.\mathrm{T}_{\mathrm{m}}=98^{\circ} \mathrm{C}\right)$, whereas the clearing point is close to the ditetradecyloxy homolog $\left(t-23: \mathrm{T}_{\mathrm{c}}=181^{\circ} \mathrm{C}\right)$. A comparison of the LC phases of these "unsymmetrical" TTTs $(t-73, t-74, t-76)$ with the thermal characteristics of the 3,4-didecyloxy isomer $\left(\boldsymbol{t}\right.$-19: $\left.\mathrm{Cr} 89 \mathrm{Col}_{\mathrm{hd}} 207 \mathrm{I}\right)$ reveals that reduction of parity reduces liquid crystallinity. This is further substantiated by the following example: when changing the notoriously mesomorphic TTTs with a 3,4-disubstituted periphery from 3,4-didecyloxy $t$-19 to 3-decyloxy-4-decyloxycarbonyl $\boldsymbol{t}$-77, the LC character vanishes (SI). Thermal transitions of $\boldsymbol{t}$-78 with a 3,4-dihexyloxy-5-dodecyloxy periphery (Cr $127 \mathrm{M} 158 \mathrm{I}$ ) appear nearly at the same temperatures as of $t$-36 with three dodecyloxy chains ( $\mathrm{Cr} 128 \mathrm{Col}_{\text {hd }} 153 \mathrm{I}$ ); here, like with $\boldsymbol{t}$-76, the longest chain accounts for the clearing point. With the combination of lower symmetry and branching, $t$-79 (3,4-dihexyloxy-5-(4-ethyl)octyloxy) is rewarded by a largely reduced melting point, whereas the width of the LC phase is maintained ( $\left.\mathrm{Cr} 80 \mathrm{Col}_{\mathrm{h}} 136 \mathrm{I}, \Delta \mathrm{T}=56 \mathrm{~K} ; t-34: \Delta \mathrm{T}=58 \mathrm{~K}\right)$.

The synthesis of "nonsymmetrical" 3,5-dialkoxy-TTTs is straight forward (Scheme 2): alkylation of methyl 3,5-dihydroxybenzoate 8 with a bromoalkane, the separation of di- and monoalkylated ester $\mathbf{9}$, followed by the reaction of the latter with a second bromoalkane and conversion of the ester $\mathbf{1 0}$ via amide to the tetrazole 3 (SI). Similarly, partial alkylation of ethyl gallate with 1-bromohexane gives ethyl 3,4-dihexyloxy-5-hydroxybenzoate. Alkylation with a suitable reagent followed by the transformation of the ester to tetrazole and reaction with cyanuric chloride yields TTTs with a "nonsymmetrical" 3,4,5-trialkoxy periphery. The 3-alkoxy-4-alkoxy' disubstitution requires more steps. The alkylation of 5-bromosalicylic aldehyde 11 with the first bromoalkane, Dakin reaction to yield bromoalkoxyphenol 13 and alkylation with the second bromoalkane, followed by the Rosenmund-von Braun reaction with $\mathrm{CuCN}$ to yield nitrile $\mathbf{1 5}$ and the addition of azide lead to tetrazole $3 \mathrm{SI}$. 

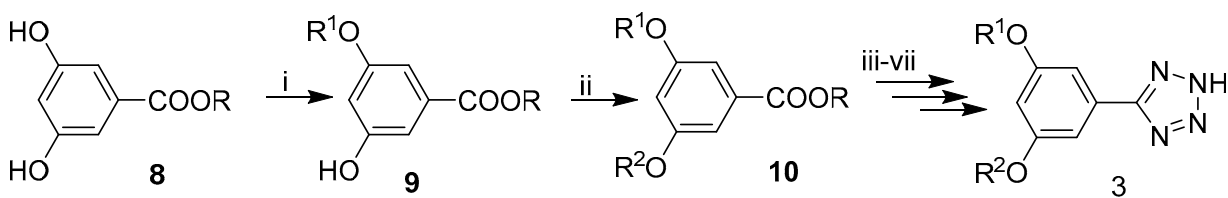

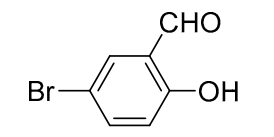

11

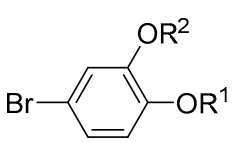

14
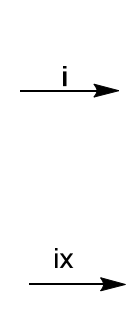

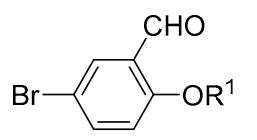

12

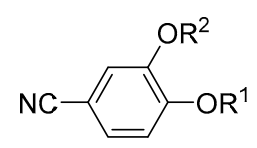

15

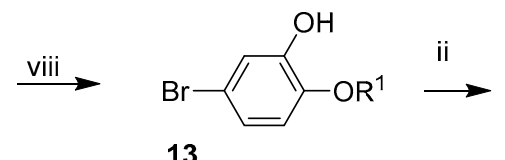

13

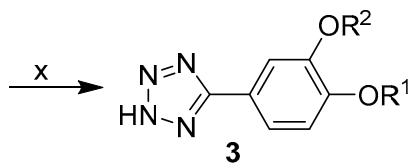

Scheme 2. Synthesis of TTTs with chains of different lengths. i: $\mathrm{R}^{1} \mathrm{Br}, \mathrm{K}_{2} \mathrm{CO}_{3}$; ii: $\mathrm{R}^{2} \mathrm{Br}, \mathrm{K}_{2} \mathrm{CO}_{3}$; iii: $\mathrm{NaOH}$, iv: $\mathrm{HCl}$; v: $\mathrm{SOCl}_{2}$; vi: $\mathrm{NH}_{3}$ aq; vii: $\mathrm{ClSi}\left(\mathrm{N}_{3}\right)_{3}$; viii: $\mathrm{mCPBA}$; ix: $\mathrm{CuCN}$; $\mathrm{Et}_{3} \mathrm{NHN}_{3}$.

\subsection{Thermal Properties of Alkoxyphenyl-Substituted TTTs with Radial Structure}

Prolonged heating at temperatures above $150^{\circ} \mathrm{C}$ provokes rearrangement of the tristriazolotriazine. In three steps, the annulation geometry changes from the original $[3,4]$-annulation of triazoles to the central triazine ring to [1,5]-annulation. This brings "tangentially" oriented alkoxyaryl substituents into "radial" positions. The flattened structure of $r$-TTTs facilitates crystallization and concomitantly enhances the melting point $[38,58]$. The 'radial' isomers of t-TTTs and their thermotropic characteristics are collected in Table 4.

In addition, 3,4- and even 3,4,5-dialkoxy substitution can give mesogens [42]. Unlike the $t$-TTT series, 3,4-didecyloxy ( $r$-19: $\mathrm{Cr} 136 \mathrm{I})$ and didodecyloxy ( $r$-21: $\left.\mathrm{Cr}_{1} 90 \mathrm{Cr}_{2} 131 \mathrm{I}\right)$-substituted $r$-TTT are crystalline. Mesomorphism starts with 13 carbons per chain (r-22: Cr 94 (16.8) M 119 (9.9) I) and those with 14 ( $r$-23: $\mathrm{Cr} 128 \mathrm{Col} 136 \mathrm{I})$ or 16 carbons per chain ( $r$-24: $\left.\mathrm{Cr} 36 \mathrm{M}_{1} 97 \mathrm{M}_{2} 125 \mathrm{Col}_{\mathrm{h}} 132 \mathrm{I}\right)$ are also DLCs. Similar to the 3,4-didodecyloxy-TTT $r$-21, its 3,5-isomer $r$-30 is not mesomorphous, but nothing more than hexyl is required for mesomorphism in the 3,4,5-trisubstituted series, $\left(r-33\right.$ : $\mathrm{Cr} 13 \mathrm{Col}_{\mathrm{h}}$ 180), and the higher octyl ( $r$-34: $\mathrm{Cr} 35 \mathrm{Col} 205 \mathrm{I})$ and decyl $\left(\boldsymbol{r}\right.$-35: $\left.\mathrm{Cr} 121 \mathrm{Col}_{\mathrm{h}} 181 \mathrm{I}\right)$ members display $^{-}$ very broad mesophases without recrystallization in DSC experiments. The hexagonal mesophases (XRD) are built from columns with a helical arrangement of the disks. A pitch of $51 \AA$, corresponding to 14 molecules, was found for $r$-34. The propensity of 3,4,5-trialkoxyphenyl-substituted cores to form broad mesophases is well-known [9] but distinctively different from the tangential isomers. Branching in the periphery ( $r$-62: $3 \times 4$-ethyloctyloxy) gives a DLC with a lower melting point and much broader mesophase ( $\left.\mathrm{Cr} 75 \mathrm{Col}_{\mathrm{h}} 207 \mathrm{I}\right)$ than that found for the isomer $r$-35 with linear decyl chains (Cr $\left.126 \mathrm{Col}_{\mathrm{h}} 165 \mathrm{I}\right)$. Though swallow-tails in the para-position are a successful way to $t$-TTTs with broad mesophases at low temperature, this concept fails for the $r$-isomers. 2-Decyldodec-1-yl results in crystalline $r-66$ with $\mathrm{T}_{\mathrm{m}}=6{ }^{\circ} \mathrm{C}$. The low enthalpy $(\Delta \mathrm{H}=0.7 \mathrm{~kJ} / \mathrm{mol})$ is attributed to incomplete crystallization. The swallow-tail drastically reduces the melting point, and the related $r-19$ with two vicinal decyloxy chains melt about $130^{\circ} \mathrm{C}$ higher. Swallow-tail 2-octyldecyloxy in the $m$-position on $t$-TTT $t$-63 effectively inhibited crystallization $\left(\mathrm{T}_{\mathrm{m}}=-64{ }^{\circ} \mathrm{C}\right)$, but the $r$-isomer $r$-63 melts only at $75^{\circ} \mathrm{C}$ without any sign of mesomorphism. Additional branching (2-(2-ethylhexyl)-4-ethyloctyloxy) stiffens the flexible parts, thus increasing the melting point of $r-71$ (Cr $136 \mathrm{I})$, identical to the didecyloxy analog $r$-19. Reducing the symmetry, 3-butoxy-5-hexadecyloxy $t$-73, does not provoke mesomorphism $(\mathrm{Cr} 99$ I), but the slightly more balanced 3-hexyloxy-5-tetradecyloxy isomer $t-74$ is liquid crystalline even at room temperature (Cr $13 \mathrm{M} 70 \mathrm{I})$.

The structure of TTT $r$-33 with a 3,4,5-trihexyloxyphenyl substitution was studied via X-ray diffraction and in silico [61]. $r-33$ is a DLC with a broad mesophase $(\Delta \mathrm{T}=167 \mathrm{~K})$ and hexagonal columnar structure. The experimental cell parameters are $a_{\text {hex }}=28.1 \AA$ and $c=3.49 \AA$, and the density 
is $0.92 \mathrm{~g} / \mathrm{cm}^{3}$. The model of an ensemble of 16 TTTs $\boldsymbol{r}-33$ in a supercell is depicted in Figure 8 [61] As a result, the self-assembly is stabilized by large van der Waals $(-1467 \mathrm{kcal} / \mathrm{mol})$ and electrostatic energy $(-547 \mathrm{kcal} / \mathrm{mol})$, whereas the packing results in a slight increase in valence energy $(197 \mathrm{kcal} / \mathrm{mol})$ owing to the geometric adaption of the molecular scaffold. Again, the mesogen cores are offset from the center of the columns and trialkoxy phenyl rings are preferentially located over the triazine cores.

A comparison of the 3,4,5-trihexyloxyphenyl-substituted DLCs $r-33$ and $t-33$ reveals a cell parameter $a$ for the $r$-isomer being $2.5 \AA$ higher than for $t$-33. This can be attributed not only to the more compact packing of $t$-33 versus $r$-33 but also to the radial topology, which generates space between the arms of the star-shaped mesogen, which is not as easily filled compared with the $t-33$ derivative. As a result, the disorder in $r-33$ is higher, which accounts for the much lower melting point of $r-33\left(13^{\circ} \mathrm{C}\right)$ compared to $t-33\left(116^{\circ} \mathrm{C}\right)$.

Table 4. Substitution pattern of $r$-TTTs and thermal properties.

\begin{tabular}{|c|c|c|c|}
\hline Entry & Substitution Pattern & Transition $/{ }^{\circ} \mathrm{C}$ (Enthalpy/kJ/mol) & Ref \\
\hline$r-1$ & $\mathrm{R}^{\mathrm{i}}=\mathrm{H}$ & $\mathrm{Cr}>390$ & [58] \\
\hline$r-2$ & $\mathrm{R}^{4}=\mathrm{OC}_{3} \mathrm{H}_{7}$ & $\mathrm{Cr}>350$ & [42] \\
\hline$r-3$ & $\mathrm{R}^{4}=\mathrm{OC}_{6} \mathrm{H}_{13}$ & Cr 178 I & SI \\
\hline$r-5$ & $\mathrm{R}^{4}=\mathrm{OC}_{10} \mathrm{H}_{21}$ & Cr 142 I & SI \\
\hline$r-15$ & $\mathrm{R}^{3}=\mathrm{R}^{4}=\mathrm{OC}_{6} \mathrm{H}_{13}$ & Cr 146 I & SI \\
\hline$r-19$ & $\mathrm{R}^{3}=\mathrm{R}^{4}=\mathrm{OC}_{10} \mathrm{H}_{21}$ & Cr 136 I & [42] \\
\hline$r-21$ & $\mathrm{R}^{3}=\mathrm{R}^{4}=\mathrm{OC}_{12} \mathrm{H}_{25}$ & $\mathrm{Cr}_{1} 90 \mathrm{Cr}_{2}$ 131(25.2) I & [42] \\
\hline$r-22$ & $\mathrm{R}^{3}=\mathrm{R}^{4}=\mathrm{OC}_{13} \mathrm{H}_{27}$ & Cr 94 (16.8) M 119 (9.9) I & SI \\
\hline$r-23$ & $\mathrm{R}^{3}=\mathrm{R}^{4}=\mathrm{OC}_{14} \mathrm{H}_{29}$ & Cr 128 (25.4) Col 136 (1.6) I & [42] \\
\hline$r-24$ & $\mathrm{R}^{3}=\mathrm{R}^{4}=\mathrm{OC}_{16} \mathrm{H}_{33}$ & $\mathrm{Cr} 36 \mathrm{M}_{1} 97 \mathrm{M}_{2} 125(23.4) \mathrm{Col}_{\mathrm{h}} 132$ (1.4) I & [42] \\
\hline$r-30$ & $\mathrm{R}^{3}=\mathrm{R}^{5}=\mathrm{OC}_{12} \mathrm{H}_{25}$ & Cr 127 I & SI \\
\hline$r-33$ & $\mathrm{R}^{3}=\mathrm{R}^{4}=\mathrm{R}^{5}=\mathrm{OC}_{6} \mathrm{H}_{13}$ & Cr 13 (8.9) Col$_{h} 180$ (3.0) I & SI \\
\hline$r-34$ & $\mathrm{R}^{3}=\mathrm{R}^{4}=\mathrm{R}^{5}=\mathrm{OC}_{8} \mathrm{H}_{17}$ & Cr 35 (16.9) [a] Col 205 (2.7) I & SI \\
\hline$r-35$ & $\mathrm{R}^{3}=\mathrm{R}^{4}=\mathrm{R}^{5}=\mathrm{OC}_{10} \mathrm{H}_{21}$ & Cr $121 \mathrm{Col}_{\mathrm{h}} 181$ (3.0) I [a] & SI \\
\hline$r-61$ & $\mathrm{R}^{3}=\mathrm{R}^{4}=\mathrm{R}^{5}=\mathrm{O}-\mathrm{CH}_{2} \mathrm{CH}\left(\mathrm{C}_{2} \mathrm{H}_{5}\right) \mathrm{C}_{4} \mathrm{H}_{9}$ & Cr $241 \mathrm{I}[\mathrm{b}]$ & SI \\
\hline$r-62$ & $\mathrm{R}^{3}=\mathrm{R}^{4}=\mathrm{R}^{5}=\mathrm{O}-\left(\mathrm{CH}_{2}\right)_{3} \mathrm{CH}\left(\mathrm{C}_{2} \mathrm{H}_{5}\right) \mathrm{C}_{4} \mathrm{H}_{9}$ & Cr 75 (2.8) Col 207(4.8) I & [42] \\
\hline$r-63$ & $\mathrm{R}^{3}=\mathrm{OCH}_{2} \mathrm{CH}\left(\mathrm{C}_{8} \mathrm{H}_{17}\right)_{2}$ & Cr 75 I & SI \\
\hline$r-66$ & $\mathrm{R}^{4}=\mathrm{OCH}_{2} \mathrm{CH}\left(\mathrm{C}_{10} \mathrm{H}_{21}\right)_{2}$ & Cr $6(0.7) \mathrm{I}$ & SI \\
\hline$r-71$ & $\mathrm{R}^{4}=\mathrm{O}-\mathrm{CH}_{2} \mathrm{CH}\left(\mathrm{CH}_{2} \mathrm{CH}\left(\mathrm{C}_{2} \mathrm{H}_{5}\right) \mathrm{C}_{4} \mathrm{H}_{9}\right)_{2}$ & Cr 136 I & SI \\
\hline$r-73$ & $\mathrm{R}^{3}=\mathrm{OC}_{4} \mathrm{H}_{9}, \mathrm{R}^{5}=\mathrm{OC}_{16} \mathrm{H}_{33}$ & Cr 99 (6.5) I & SI \\
\hline$r-74$ & $\mathrm{R}^{3}=\mathrm{OC}_{6} \mathrm{H}_{13}, \mathrm{R}^{5}=\mathrm{OC}_{14} \mathrm{H}_{29}$ & Cr 13 (4.4) M 70 (3.4) I & SI \\
\hline$r-80$ & $\mathrm{R}^{3}=\mathrm{Cl}, \mathrm{R}^{4}=\mathrm{OC}_{6} \mathrm{H}_{13}$ & Cr $178 \mathrm{I}$ & SI \\
\hline
\end{tabular}

[a] values from 1, heating scan; [b] determined by POM; Tg: glass transition temperature. 


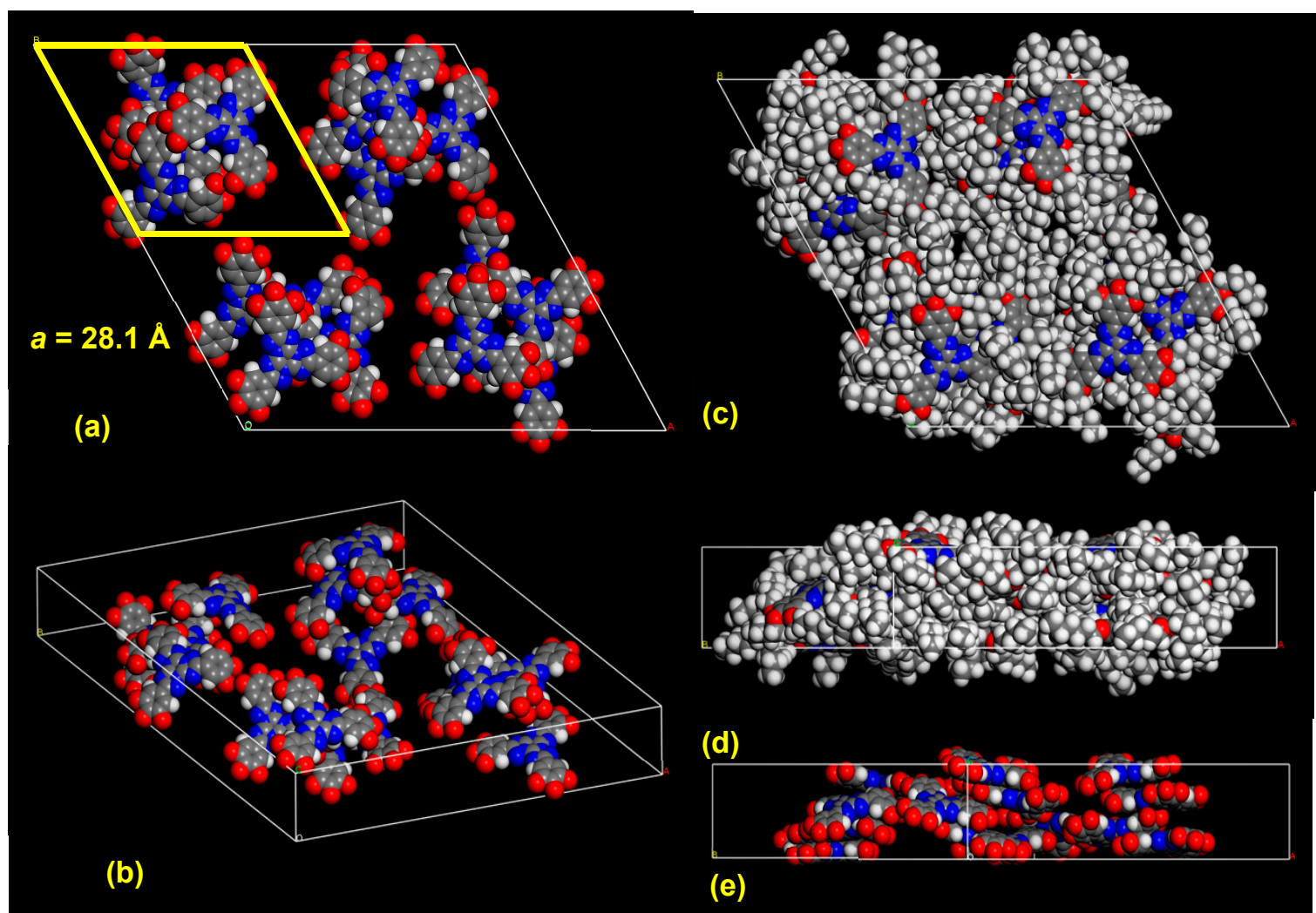

Figure 8. Model of a supercell $(2 a \times 2 a \times 4 c)$ of $\boldsymbol{r}$-33. (a,b) Top view, where hexyl chains are omitted; (c,d) top and side view, including hexyl chains; (e) side view, where hexyl chains are omitted.

\section{Conclusions}

An extensive study of mesomorphous TTTs with di- or trialkoxyphenyl substitution reveals that the 3,4-dialkoxy pattern is nearly a guarantee for broad mesophases, whereas no 2-alkoxy chain is tolerated. 3,5-Di- and 3,4,5-trialkoxy derivatives with comparable numbers of methylene groups show similar phase widths, and the 3,5-pattern gives lower melting points. The main effect of increasing chain lengths is the reduction of clearing points. A similar effect provokes short-chain branching on the 3,4-pattern, but this is disastrous on the 3,4,5-derivatives. One swallow-tail chain per phenyl ring of $t$-TTTs largely reduces the melting point. If this group is in the para-position, broad mesophases are obtained. On the other hand, no $r$-TTT with a swallow-tail chain is a DLC. TTTs with chains of identical lengths are LCs with broader mesophases at higher temperatures compared to their isomers with chains of different lengths. Moderate irregularity such as short-chain branching and varying chain lengths is an effective tool to tune thermal properties. The longest chains appear to control the clearing point. This study shows that the thermal properties of TTTs are highly dependent on the substitution pattern, with individual consequences on $t$ - and $r$-TTTs; however, within some homologous series, property changes seem to be predictable.

Supplementary Materials: The following are available online, Experimental procedures, spectroscopical and analytical data, NMR spectra, DSC and POM.

Author Contributions: Conceptualization: H.D.; XRD: M.L., T.R., N.T. and D.L.; synthesis, spectroscopy and thermal analysis: T.R., N.T., P.W., N.S., M.S., S.G., H.D. and T.H.; writing-original draft preparation, H.D.; writing - review and editing, H.D. and M.L.; project administration, H.D.; funding acquisition, H.D. All authors have read and agreed to the published version of the manuscript.

Funding: This research was funded by Deutsche Forschungsgemeinschaft, grant number DE 515/9-1 and DE 515/12-1.

Acknowledgments: The authors thank M. Müller (DSC), J. Liermann, and D. Schollmeyer (XRD) for many measurements. 
Conflicts of Interest: The authors declare no conflict of interest.

\section{References}

1. Cristiano, R.; Gallardo, H.; Bertoluzzi, A.J.; Bechtold, I.H.; Campos, C.E.M.; Longo, R.L. Tristriazolotriazines: A core for luminescent discotic liquid crystals. Chem. Commun. 2008, 41, 5134-5136. [CrossRef]

2. Cristiano, R.; Eccher, J.; Bechtold, I.H.; Tironi, C.N.; Vieira, A.A.; Molin, F.; Gallardo, H. Luminescent columnar liquid crystals based on tristriazolotriazine. Langmuir 2012, 28, 11590-11598. [CrossRef]

3. Glang, S.; Schmitt, V.; Detert, H. Tristriazolotriazine-A novel heteroaromatic core for discotic liquid crystals. In Proceedings of the 36th German Topical Meeting on Liquid Crystals, Magdeburg, Germany, 12-14 March 2008; pp. 125-128.

4. Glang, S.; Rieth, T.; Borchmann, D.; Fortunati, I.; Signorini, R.; Detert, H. Arylethynyl-Substituted Tristriazolotriazines: Synthesis, Optical Properties, and Thermotropic Behavior. Eur. J. Org. Chem. 2014, 2014, 3116-3126. [CrossRef]

5. Bushby RJ Lozman, O.R. Discotic liquid crystals 25 years on. Curr. Opin. Colloid Interface Sci. 2002, 7, 343-354. [CrossRef]

6. Laschat, S.; Baro, A.; Steinke, N.; Giesselmann, F.; Hägele, C.; Scalia, G.; Judele, R.; Kapatsina, E.; Sauer, S.; Schreivogel, A.; et al. Diskotische Flüssigkristalle: Von der maßgeschneiderten Synthese zur Kunststoffelektronik. Angew. Chem. 2007, 119, 4916-4973. [CrossRef]

7. Kumar, S. Perspectives. In Chemistry of Discotic Liquid Crystals; CRC Press: Boca Raton, FL, USA, 2011; pp. 447-492.

8. Sergeyev, S.; Pisula, W.; Geerts, Y.H. Discotic Liquid Crystals: A New Generation of Organic Semiconductors. Chem. Soc. Rev. 2008, 36, 1902-1929. [CrossRef] [PubMed]

9. Wöhrle, T.; Wurzbach, I.; Kirres, J.; Kostidou, A.; Kapernaum, N.; Litterscheidt, J.; Haenle, J.C.; Staffeld, P.; Baro, A.; Giesselmann, F.; et al. Discotic Liquid Crystals. Chem. Rev. 2016, 116, 1139-1241. [CrossRef] [PubMed]

10. Pisula, W.; Muellen, K. Discotic liquid crystals as semi-conductors. In Handbook of Liquid Crystals, 2nd ed.; Goodby, J.W., Ed.; Wiley-VCH: Weinheim, Germany, 2014; Volume 8, pp. 627-673.

11. Kaafarani, B.R. Discotic Liquid Crystals for Opto-Electronic Applications. Chem. Mater. 2011, 23, 378-396. [CrossRef]

12. Detert, H.; Lehmann, M.; Meier, H. Star-shaped Conjugated Systems. Materials 2010, 3, 3218-3330. [CrossRef]

13. Boden, N.; Bushby, R.J.; Clements, J.M.; Movaghar, B. Device applications of charge transport in discotic liquid crystals. J. Mater. Chem. 1999, 9, 2081-2086. [CrossRef]

14. Volpi, R.; Camilo, A.C.S.; da Silva Filho, D.A.; Navarrete, J.T.L.; Gomez-Lor, B.; Delgado, M.C.R.; Linares, M. Modeling charge transport of discotic liquid crystalline triindoles: The role of peripheral substitution. Phys. Chem. Chem. Phys. 2017, 19, 24202-24208. [CrossRef] [PubMed]

15. Bi, J.; Wu, H.; Zhang, Z.; Zhang, A.; Yang, H.; Feng, Y.; Fang, Y.; Zhang, L.; Wang, Z.; Qu, W. Highly ordered columnar superlattice nanostructures with improved charge carrier mobility by thermotropic self-assembly of triphenylene-based discotics. J. Mater. Chem. C 2019, 7, 12463-12469. [CrossRef]

16. Navarro, A.; Fernández-Liencres, M.P.; Garcia, G.; Granadino-Roldán, J.M.; Fernández-Gómez, M. A DFT approach to the charge transport related properties in columnar stacked $\pi$-conjugated $\mathrm{N}$-heterocycle cores including electron donor and acceptor units. Phys. Chem. Chem. Phys. 2015, 17, 605-618. [CrossRef] [PubMed]

17. Brzeczek, A.; Ledwon, P.; Data, P.; Zassowski, P.; Golba, S.; Walczak, K.; Lapkowski, M. Synthesis and Properties of 1,3,5-Tricarbazolylbenzenes with Star-Shaped Architecture. Dyes Pigments 2015, 113, 640-648. [CrossRef]

18. Bagnich, S.A.; Athanasopoulos, S.; Rudnick, A.; Schroegel, P.; Bauer, I.; Greenham, N.C.; Strohriegl, P.; Koehler, A. Excimer Formation by Steric Twisting in Carbazole and Triphenylamine-Based Host Materials. J. Phys. Chem. C 2015, 119, 2380-2387.

19. Kozlov, O.V.; Luponosov, Y.N.; Ponomarenko, S.A.; Kausch-Busies, N.; Paraschuk, D.Y.; Olivier, Y.; Beljonne, D.; Cornil, J.; Pshenichnikov, M.S. Ultrafast Charge Generation Pathways in Photovoltaic Blends Based on Novel Star-Shaped Conjugated Molecules. Adv. Energy Mater. 2015, 5, 1401657. [CrossRef]

20. Jiang, Y.; Yu, D.; Lu, L.; Zhan, C.; Wu, D.; You, W.; Wei, X.; Xie, Z.; Xiao, S. Tuning optical and electronic properties of star-shaped conjugated molecules with enlarged $\pi$-delocalization for organic solar cell application. J. Mater. Chem. A 2013, 1, 8270-8279. [CrossRef] 
21. Metri, N.; Sallenave, X.; Beouch, L.; Plesse, C.; Goubard, F.; Chevrot, C. New star-shaped molecules derived from thieno[3, 2-b] thiophene unit and triphenylamine. Tetrahedron Lett. 2010, 51, 6673-6676. [CrossRef]

22. Leriche, P.; Piron, F.; Ripaud, E.; Frere, P.; Allain, M.; Roncali, J. Star-shaped triazine-thiophene conjugated systems. Tetrahedron Lett. 2009, 50, 5673-5676. [CrossRef]

23. Ponomarenko, S.A.; Tatarinova, E.A.; Muzafarov, A.M.; Kirchmeyer, S.; Brassat, L.; Mourran, A.; Moeller, M.; Setayesh, S.; De Leeuw, D. Star-shaped oligothiophenes for solution-processible organic electronics: Flexible aliphatic spacers approach. Chem. Mater. 2006, 18, 4101-4108. [CrossRef]

24. Liu, C.-F.; Cheng, C.; Jiang, Y.; Lai, W.-Y.; Huang, W. Nitrogen-doped star-shaped polycyclic aromatic hydrocarbons based on fused triazatruxenes: Synthesis and optoelectronic properties. New J. Chem. 2017, 41, 13619. [CrossRef]

25. El Sayed, M.T. Synthetic Routes to Electroactive Organic Discotic Aromatic Triazatruxenes. J. Heterocycl. Chem. 2018, 55, 21-43. [CrossRef]

26. Lehmann, M.; Kestemont, G.; Aspe, R.G.; Buess-Herman, C.; Koch, M.H.J.; Debije, M.G.; Piris, J.; de Haas, M.P.; Warman, J.M.; Watson, M.D.; et al. High charge-carrier mobility in $\pi$-deficient discotic mesogens: Design and structure-property relationship. Chem. Eur. J. 2005, 11, 3349-3362. [CrossRef]

27. Huang, C.-Y.; Lee, W.-H.; Lee, R.-H. Solution processable star-shaped molecules with a triazine core and branching thienylenevinylenes for bulk heterojunction solar cells. RSC Adv. 2014, 4, 48150-48162. [CrossRef]

28. Pradhan, B.; Pathak, S.K.; Gupta, R.K.; Gupta, M.; Pal, S.K.; Achalkumar, A.S. Star-shaped fluorescent liquid crystals derived from s-triazine and 1,3,4-oxadiazole moieties. J. Mater. Chem. C 2016, 4, 6117-6130. [CrossRef]

29. Lukes, V.; Rapta, P.; Idzik, K.R.; Beckert, R.; Dunsch, L. Charged States of 1,3,5-Triazine Molecules as Models for Star-shaped Molecular Architecture: A DFT and spectroelectrochemcial Study. J. Phys. Chem. B 2011, 115, 3344-3353. [CrossRef]

30. Ishi-i, T.; Moriyama, Y.; Kusakaki, Y. Turn-on-type emission enhancement and ratiometric emission color change based on the combination effect of aggregation and TICT found in the hexaazatriphenylene-triphenylamine dye in an aqueous environment. RSC Adv. 2016, 6, 86301. [CrossRef]

31. Blas-Ferrando, V.M.; Ortiz, J.; Follana-Berna, J.; Fernandez-Lazaro, F.; Sastre-Santos, A.; Campos, A.; Mas-Torrent, M. Large-Size Star-Shaped Conjugated (Fused) Triphthalocyaninehexaazatriphenylene. Org. Lett. 2016, 18, 1466-1469. [CrossRef]

32. Segura, J.L.; Juarez, R.; Ramos, M.; Seoane, C. Hexaazatriphenylene (HAT) derivatives: From synthesis to molecular design, self-organization and device applications. Chem. Soc. Rev. 2015, 44, 6850-6885. [CrossRef]

33. Gearba, R.I.; Lehmann, M.; Levin, J.; Ivanov, D.A.; Koch, M.H.J.; Barbera, J.; Debije, M.G.; Piris, J.; Geerts, Y.H. Tailoring Discotic Mesophases: Columnar Order Enforced with Hydrogen Bonds. Adv. Mater. 2003, 15, 1614-1618. [CrossRef]

34. Cammidge, A.N.; Cook, M.J.; Harrison, K.J.; McKeown, N.B. Synthesis and characterisation of some 1,4,8,11,15,18,22,25-octa(alkoxymethyl)phthalocyanines; a new series of discotic liquid crystals. J. Chem. Soc. Perkin. 1991, 12, 3053-3058. [CrossRef]

35. Tober, N.; Rieth, T.; Lehmann, M.; Detert, H. Synthesis, Thermal, and Optical Properties of Tris(5-aryl-1,3,4-oxadiazol-2-yl)-1,3,5-triazines, New Star-shaped Fluorescent Discotic Liquid Crystals. Chem. Eur. J. 2019, 25, 15295-15304. [CrossRef] [PubMed]

36. Röder, N.; Marzalek, T.; Limbach, D.; Pisula, W.; Detert, H. Tetrakis(oxadiazolylphenyl)pyrazines: New St. Andrew's Cross-Shaped Liquid Crystals. ChemPhysChem 2019, 20, 463-469. [CrossRef] [PubMed]

37. Glang, S.; Borchmann, D.; Rieth, T.; Detert, H. Tristriazolotriazines with $\pi$-Conjugated Segments: Star-shaped Fluorophors and Discotic Liquid Crystals. Adv. Sci. Technol. 2013, 77, 118-123. [CrossRef]

38. Rieth, T.; Marszalek, T.; Pisula, W.; Detert, H. Thermotropic Properties and Molecular Packing of Discotic Tristriazolotriazines with Rigid Substituents. Chem. Eur. J. 2014, 20, 5000-5006. [CrossRef]

39. Sperner, M.; Tober, N.; Detert, H. Tristriazolotriazines with Azobenzene Arms-Acidochromic Dyes and Discotic Liquid Crystals. Eur. J. Org. Chem. 2019, 4688-4693. [CrossRef]

40. Detert, H. Tristriazolotriazines-Luminescent Discotic Liquid Crystals. Eur. J. Org. Chem. 2018, 2018, 4501-4507. [CrossRef]

41. Herget, K.; Schollmeyer, D.; Detert, H. 3,7,11-Tris\{4-[(1R,3S,4S)-neomenthyloxy]phenyl\}tri[1,2,4]triazolo [4,3-a:4', 3'-c:4",3"-e][1,3,5]triazine-chloroform-ethanol (1/1/1). Acta Cryst. E 2013, 69, 365. [CrossRef]

42. Rieth, T.; Röder, N.; Lehmann, M.; Detert, H. Isomerisation of Liquid-Crystalline Tristriazolotriazines. Chem. Eur. J. 2018, 24, 93-96. [CrossRef] 
43. Dal-Bó, A.G.; López Cisneros, G.G.; Cercena, R.; Mendes, J.; Matos de Silveira, L.; Zapp, E.; Dominicano, K.G.; da Costa Duarte, R.; Rodembusch, F.S.; Allievi Frizon, T.E. Synthesis, electrochemical, thermal and photophysical characterization of photoactive discotic dyes based on the tris-[1,2,4]-triazolo-[1,3,5]-triazine core. Dyes Pigments 2016, 135, 49-56. [CrossRef]

44. Destrade, C.; Mondon, M.C.; Malthete, J. Hexasubstituted triphenylenes: A New Mesomorphic Order. J. Phys. Colloque 1979, 40, C3-17. [CrossRef]

45. Malthete, J.; Destrade, C.; Tinh, N.H.; Jacques, J.A. Pure Disc-Like Molecule with Cholesteric Properties. Mol. Cryst. Liq. Cryst 1981, 64, 233-238. [CrossRef]

46. Ong, C.W.; Liao, S.C.; Chang, T.H.; Hsu, H.F. Rapid synthesis of new discotic liquid crystals based on diquinoxalino[2,3-a:2', $3^{\prime}$-c]phenazine containing hexakis(alkoxy) side arms. Tetrahedron Lett. 2003, 44, 1477-1480. [CrossRef]

47. Bock, H.; Bebeau, A.; Seguy, I.; Jolinat, P.; Destruel, P. Crystal and Electronic Structure of a Fluorescent Columnar Liquid Crystalline Electron Transport Material. ChemPhysChem 2002, 3, 532-535. [CrossRef]

48. Holst, H.C.; Pakula, T.; Meier, H. Liquid crystals in the series of 2,4,6-tristyryl-1,3,5-triazines. Tetrahedron 2004, 60, 6765-6775. [CrossRef]

49. Foster, E.J.; Lavingueur, C.; Ke, Y.C.; Williams, V.E. Modular assembly of elliptical mesogens. Liq. Cryst. 2007, 34, 833-840.

50. Paganuzzi, V.; Guatteri, P.; Riccardi, P.; Sacchelli, T.; Barbera, J.; Costa, M.; Dalcanale, E. Synthesis and Mesogenic Properties of Porphyrin Octaesters. Eur. J. Org. Chem. 1999, 1999, 1527-1539. [CrossRef]

51. Yu, M.; Zhang, W.Y.; Fan, Y.; Jian, W.P.; Liu, G.F. [5-(p-alkoxy)phenyl-10, 15, 20-tri-phenyl] porphyrin and their rare earth complex liquid crystalline. J. Phys. Org. Chem. 2007, 20, 229-235. [CrossRef]

52. Bhyrappa, P.; Arunkumar, C.; Varghese, B.; Rao, D.S.S.; Prasad, S.K. Synthesis and mesogenic properties of $\beta$-tetrabrominated tetraalkyloxyporphyrins. Porphyr. Phthalocyanines 2008, 12, 54-64. [CrossRef]

53. Lelj, F.; Morelli, G.; Ricciardi, G.; Roviello, A.; Sirigu, A. Discotic mesomorphism of 2,3,7,8,12,13,17,18-octakis (alkyl-thio) 5,10,15,20 tetraaza porphyrin and its complexes with some divalent transition metal ions. Synthesis and characterization. Liq. Cryst. 1992, 12, 941-960. [CrossRef]

54. van der Pol, J.F.; Neeleman, E.; Zwikker, J.W.; Nolte, R.J.M.; Drenth, W.; Aerts, J.; Visser, R.; Picken, S. Liquid-crystalline phthalocyanines revisited. Liq. Cryst. 2006, 33, 1373-1387.

55. Ban, K.; Nishizawa, K.; Ohta, K.; Shirai, H. Discotic liquid crystals of transition metal complexes 27: Supramolecular structure of liquid crystalline octakisalkylthiophthalocyanines and their copper complexes. J. Mater. Chem. 2000, 10, 1083-1090. [CrossRef]

56. Huisgen, R.; Sturm, H.J.; Seidel, M. Ringöffnungen der Azole, V. Weitere Reaktionen der Tetrazole mit elektrophilen Agenzien. Chem. Ber. 1961, 94, 1555-1562. [CrossRef]

57. El-Ahl, A.; Elmorsy, S.; Elbeheery, A. A novel approach for the synthesis of 5-substituted tetrazole derivatives from primary amides in mild one-step method. Tetrahedron Lett. 1997, 38, 1257-1260. [CrossRef]

58. Tartakovsky, V.A.; Frumkin, A.E.; Churakov, A.M.; Strelenko, Y.A. New approaches to synthesis of tris[1,2,4]triazolo[1,3,5]triazines. Russ. Chem. Bull. Int. Ed. 2005, 54, 719-726. [CrossRef]

59. Limbach, D.; Detert,H.; Schollmeyer, D. 2,6,10-Trichloro-tris([1,2,4]triazolo)[1,5-a:1',5'-c:1", 5"'-e]-1,3,5-triazine. IUCR Data 2018, 3, x180212. [CrossRef]

60. Rieth, T.; Glang, S.; Borchmann, D.; Detert, H. 3,5-Dialkoxy substituted triphenyl-tristriazolotriazines: Fluorescent discotic liquid crystals. Mol. Cryst. Liq. Cryst. 2015, 610, 89-99. [CrossRef]

61. Simulations were performed using Accelrys Materials Studio 2017 R2 using the CompassII force field. Module: Forcite; Force Field: COMPASSII, Algorithm: Smart; Quality: Medium (Energy 0,001 kcal/mol; Force $0.5 \mathrm{kcal} / \mathrm{mol} / \mathrm{A})$; Summation method: Ewald

62. Cammidge, A.N. The effect of size and shape variation in discotic liquid crystals based on triphenylene cores. Philos. Trans. R. Soc. Math. Phys. Eng. Sci. 2006, 364, 2697-2708. [CrossRef]

63. Kumar, S.; Varschney, S.K. A Room-Temperature Discotic Nematic Liquid Crystal. Angew. Chem. Int Ed. 2000, 39, 3140-3142. [CrossRef]

64. Bisoy, H.K.; Kumar, S. Room-temperature electron-deficient discotic liquid crystals: Facile synthesis and mesophase characterization. New J. Chem. 2008, 32, 1974-1980. [CrossRef]

65. Sergeyev, S.; Pouzet, E.; Debever, O.; Levin, J.; Gierschner, J.; Cornil, J.; Aspe, R.G.; Geerts, Y.H. Liquid crystalline octaalkoxycarbonyl phthalocyanines: Design, synthesis, electronic structure, self-aggregation and mesomorphism. J. Mater. Chem. 2007, 17, 1774-1784. [CrossRef] 
66. Liu, C.Y.; Fechtenkötter, A.; Watson, M.D.; Müllen, K.; Bard, A.J. Room Temperature Discotic Liquid Crystalline Thin Films of Hexa-peri-hexabenzocoronene: Synthesis and Optoelectronic Properties. Chem. Mater. 2003, 15, 124-130. [CrossRef]

67. Pisula, W.; Kastler, M.; Wasserfallen, D.; Mondeshki, M.; Piris, J.; Schnell, I.; Müllen, K. Relation between Supramolecular Order and Charge Carrier Mobility of Branched Alkyl Hexa-peri-hexabenzocoronenes. Chem. Mater. 2006, 18, 3634-3640. [CrossRef]

68. Seo, S.H.; Jones, T.V.; Seyler, H.; Peters, J.O.; Kim, T.H.; Chang, J.Y.; Tew, G.N. Liquid Crystalline Order from ortho-Phenylene Ethynylene Macrocycles. J. Am. Chem. Soc. 2006, 128, 9264-9265. [CrossRef] [PubMed]

69. van de Craats, A.M.; Bunk, O.; Nielsen, M.M.; Watson, M.; Müllen, K.; Chanzy, H.D.; Sirringhaus, H.; Friend, R.H. Meso-Epitaxial Solution-Growth of Self-Organizing Discotic Liquid-Crystalline Semiconductors. Adv. Mat. 2003, 15, 495-499. [CrossRef]

70. Budig, H.; Lunkwitz, R.; Paschke, R.; Tschierske, C.; Nuetz, U.; Diele, S.; Pelzl, G. The influence of heteroatoms and branchings on the liquid-crystalline properties of cyclotriveratrylene derivatives. J. Mater. Chem. 1996, 6, 1283-1289. [CrossRef]

71. Lee, M.; Kim, J.-W.; Peleshanko, S.; Larson, K.; Yoo, Y.-S.; Vaknin, D.; Markutsya, S.; Tsukruk, V.V. Amphiphilic hairy disks with branched hydrophilic tails and a hexa-peri-hexabenzocoronene core. J. Am. Chem. Soc. 2002, 124, 9121-9128. [CrossRef]

72. De, J.; Gupta, S.P.; Bala, I.; Kumar, S.; Pal, S.K. Phase Behavior of a New Class of Anthraquinone-Based Discotic Liquid Crystals. Langmuir 2017, 33, 13849-13860. [CrossRef]

73. Pathak, S.K.; Nath, S.; De, J.; Pal, S.K.; Achalkumar, A.S. Contrasting effects of heterocycle substitution and branched tails in the arms of star-shaped molecules. New J. Chem. 2017, 41, 4680-4688. [CrossRef]

74. Feng, C.; Ding, Y.-H.; Han, X.-D.; Yu, W.-H.; Xiang, S.-K.; Wang, B.-Q.; Hu, P.; Li, L.-C.; Chen, X.-Z.; Zhao, K.-Q. Triphenylene 2, 3-dicarboxylic imides as luminescent liquid crystals: Mesomorphism, optical and electronic properties. Dyes Pigments 2017, 139, 87-96. [CrossRef]

75. Laschat, S.; Baro, A.; Woehrle, T.; Kirres, J. Playing with nanosegregation in discotic crown ethers: From molecular design to OFETs, nanofibers and luminescent materials. Liq. Cryst. Today 2016, 25, 48-60. [CrossRef]

76. Kirres, J.; Knecht, F.; Seubert, P.; Baro, A.; Laschat, S. $\delta$-Methyl Branching in the Side Chain Makes the Difference: Access to Room-Temperature Discotics. ChemPhysChem 2016, 17, 1159-1165. [CrossRef] [PubMed]

77. Varshney, S.K.; Prasad, V.; Takezoe, H. Spontaneous Achiral Symmetry Breaking in Liquid Crystalline Phases. Liq. Cryst. 2011, 38, 53-60. [CrossRef]

78. Mahoney, S.J.; Ahmida, M.M.; Kayal, H.; Fox, N.; Shimizu, Y.; Eichhorn, S.H. Synthesis, mesomorphism and electronic properties of nonaflate and cyano-substituted pentyloxy and 3-methylbutyloxy triphenylenes. J. Mater. Chem. 2009, 19, 9221-9232. [CrossRef]

79. Stackhouse, P.J.; Hird, M. Influence of branched chains on the mesomorphic properties of symmetrical and unsymmetrical triphenylene discotic liquid crystals. Liq. Cryst. 2008, 35, 597-607. [CrossRef]

80. Weissflog, W.; Wiegeleben, A.; Diele, S.; Demus, D. Liquid crystalline swallow-tailed compounds I. Cryst. Res. Technol. 1984, 19, 583-591. [CrossRef]

81. Weissflog, W.; Letko, I.; Pelzl, G.; Diele, S. Liq. Cryst. 1995, 18, 867-870. [CrossRef]

82. Diele, S.; Oelsner, S.; Kuschel, F.; Hisgen, B.; Ringsdorf, H.; Zentel, R. X-ray investigations of liquid crystalline homo- and copolysiloxanes with paired mesogens. Makromol. Chem. 1987, 188, 1993-2000. [CrossRef]

83. Pisula, W.; Tomovic, Z.; Kolb, U.; Muellen, K. Melt Processing of Hexa-peri-hexabenzocoronene on the Water Surface. Langmuir 2011, 27, 1524-1529. [CrossRef]

84. Wicklein, A.; Lang, A.; Muth, M.; Thelakkat, M. Swallow-tail substituted liquid crystalline perylene bisimides: Ssynsthesis and thermotropic properties. J. Am. Chem. Soc. 2009, 131, 14442-14453. [CrossRef]

85. Liu, F.; Prehm, M.; Zeng, X.; Ungar, G.; Tschierske, C. Two-and three-dimensional liquid-crystal phases from axial bundles of rodlike polyphiles: Segmented cylinders, crossed columns, and ribbons between sheets. Angew. Chem. Int. Ed. 2011, 50, 10599-10602. [CrossRef] [PubMed]

86. Weck, M.; Dunn, A.R.; Matsumoto, K.; Coates, G.W.; Lobkovsky, E.B.; Grubbs, R.H. Influence of perfluoroarene-arene interactions on the phase behavior of liquid crystalline and polymeric materials. Angew. Chem. Int. Ed. 1999, 38, 2741-2745. [CrossRef]

87. Henderson, P.; Kumar, S.; Rego, J.A.; Ringsdorf, H.; Schumacher, P. The synthesis of alkoxybromotriphenylenes: New discotic liquid crystals and valuable precursors to 'mixed tail' discotics. Chem. Commun. 1995, 10, 1059-1060. [CrossRef] 
88. Kumar, S.; Manickam, M. Novel unsymmetrical triphenylene discotic liquid crystals: First synthesis of 1, 2, 3, 6, 7, 10, 11-heptaalkoxytriphenylenes. Chem. Commun. 1998, 14, 1427-1428. [CrossRef]

89. Kumar, S.; Naido, J.J.; Shankar Rao, D.S. Novel dibenzo[fg,op]naphthacene discotic liquid crystals: A versatile rational synthesis. J. Mater. Chem. 2002, 12, 1335-1341. [CrossRef]

90. Adib, Z.A.; Clarkson, G.J.; McKeown, N.B.; Treacher, K.E.; Gleeson, H.F.; Stennet, A.S. Molecular assemblies of novel amphiphilic phthalocyanines: An investigation into the self-ordering properties of complex functional materials. J. Mater. Chem. 1998, 8, 2371-2378. [CrossRef]

91. Yuksel, F.; Attila, D.; Ahsen, V. Synthesis and characterization of liquid crystalline unsymmetrically substituted phthalocyanines. Polyhedron 2007, 26, 4551-4556. [CrossRef]

92. Kumar, S.; Naidu, J.J. Novel hexasubstituted triphenylene discotic liquid crystals having three different types of peripheral substituent. Liq. Cryst. 2002, 29, 899-906. [CrossRef]

93. Cammidge, A.N.; Gopee, H. Antiaromatic twinned triphenylene discotics showing nematic phases and 2-dimensional $\pi$-overlap in the solid state. J. Mater. Chem. 2001, 11, 2773-2783. [CrossRef]

Publisher's Note: MDPI stays neutral with regard to jurisdictional claims in published maps and institutional affiliations.

(C) 2020 by the authors. Licensee MDPI, Basel, Switzerland. This article is an open access article distributed under the terms and conditions of the Creative Commons Attribution (CC BY) license (http://creativecommons.org/licenses/by/4.0/). 